UDK 012Bergamo

\title{
Zoran Krstulović
}

Narodna in univerzitetna knjižnica, Ljubljana

\section{Bibliografija Marije Bergamo}

Bibliografija prof. dr. Marije Bergamo zajema avtorska in prevedena dela s področja muzikologije, ki jih je objavila od leta 1960. Obsega 366 bibliografskih enot: monografije, znanstvene in strokovne članke, glasbene kritike, leksikografske prispevke, spremna besedila h koncertnim sporedom, glasbenim tiskom in zvočnim posnetkom ter dela, ki so nastala pod njenim mentorstvom.

Kronološki seznam del Marije Bergamo odraža njeno strokovno delo ter raziskovalne težnje $\mathrm{v}$ različnih mestih jugovzhodne in srednje Evrope, najprej v Beogradu do leta 1972, potem na Dunaju (1972-1981) ter od 1981 v Ljubljani in Zagrebu. V beograjskem obdobju je objavljala ocene in poročila o glasbenih dogodkih, večinoma v Zvuku in časopisu Pro musica, ter glasbene kritike v dnevnikih Borba (1964-1967) in Politika (1971). Poleg glasbeno-kritiškega pisanja se je ukvarjala tudi z znanstvenoraziskovalnim delom, predvsem z novejšo in sodobno srbsko glasbo, s skladateljskim delom Vojislava Vučkovića, Petra Konjovića, Stevana Hristića, Mirjane Živković, Rajka Maksimovića. Eseje o glasbi je objavljala v številnih jugoslovanskih časopisih kot so Nin, Telegram, Odjek, Naši razgledi, Ovdje. Le nekaj avtoričinih objav je znanih iz časov njenega delovanja v glasbeni redakciji založbe Universal Edition na Dunaju. Takrat je izšla njena prva knjiga Elementi ekspresionističke orijentacije u srpskoj muzici do 1945. godine, objavljena so bila njena spremna besedila k skladbam Alfreda Schnittkeja. Od leta 1981 do danes so objave znanstvenih besedil Marije Bergamo številčnejše. Njeni znanstveni članki so objavljeni predvsem v muzikoloških revijah Muzikološki zbornik, Arti musices, International review of the aesthetics and sociology of music in Zvuk, nekateri tudi v znanstvenih revijah drugih strok (npr. Sodobnost, Mogućnosti ipd.). Pogosto sodelovanje na številnih domačih in tujih simpozijih je razvidno iz številnih objav v različnih zbornikih (npr. zbornikih Slovenski glasbeni dnevi, zbornikih kolokvijev v Brnu, simpozijev v organizaciji Muzikološkega inštituta ZRC SAZU, Obdobja itd.).

V bibliografiji je popisano tudi avtoričino prevajalsko delo, prevodi nekaterih temeljnih teoretičnih del skladateljev Igorja Stravinskega, Ferruccia Busonija, Albana Berga, Arnolda Schönberga ter drugih avtorjev kot so Vasilij Kandinski in Nikolaj Kublin.

Bibliografija navaja tudi profesoričino mentorsko delo pri diplomskih nalogah, magistrskih delih in doktorskih disertacijah (seminarska dela so izpuščena).

Bibliografski popis je urejen kronološko glede na letnico objave. Zaradi preglednosti so dela navedena v okviru posameznega leta po naslednjih razdelkih: 
- monografske publikacije,

- članki,

- zapisi razprav,

- prispevki v enciklopedijah in leksikonih,

- ocene in poročila,

- spremna besedila,

- mentorstvo,

- prevodi.

Tudi znotraj posameznih razdelkov je urejevalni princip kronološki.

Pri zapisih posameznih enot se podatki vrstijo po naslednjem splošnem vzorcu: naslov, podnaslov, kraj, založba in letnica objave ter zbirka. V navedbah člankov, objavljenih v znanstveni in strokovni periodiki oz. časopisih, naslovu in morebitnem podnaslovu, sledijo v ležečem tisku navedba vira ter podatki o letniku, letnici, številki in obsegu. Pri člankih, objavljenih v zbornikih, za oznako »V:« sledijo podatki o publikaciji v naslednjem vrstnem redu: naslov z morebitnim podnaslovom (ležeči tisk), urednik, navedba podatkov o kraju objave, založniku in letnici objave ter zbirki. Dodatna pojasnila so zapisana na koncu posameznega bibliografskega opisa. Prevodi že objavljenih avtoričinih del so navedeni kot posamezne bibliografske enote, podatki o ponatisih pa so priključeni prvi objavi.

Prispevki Marije Bergamo v časniku Borba so popisani po izdaji, ki je izhajala v latinici v Zagrebu. Beograjska izdaja tega časopisa v cirilici žal ni bila dostopna. Zato so prispevki, objavljeni v beograjski izdaji, popisani po Bibliografiji Jugoslavije, kar je razvidno tudi iz opomb pri posameznih zapisih. Prav tako ni bilo mogoče preveriti ali je pri tistih prispevkih, ki so bili objavljeni hkrati v obeh izdajah Borbe, cirilska objava enaka latinični.

Zahvaljujem se bibliotekarjem Narodne in univerzitetne knjižnice, zlasti Oddelka Slovenska bibliografija, Glasbene zbirke, Zbirke serijskih publikacij ter Oddelka za izposojo in hranjenje knjižničnega gradiva, ki so s svojim prizadevanjem pri iskanju gradiva, pripravi in preverjanju podatkov pomagali pri izdelavi bibliografije. Za posredovane podatke se zahvaljujem tudi kolegom bibliotekarjem Nacionalne i sveučilišne knjižnice v Zagrebu in Narodne biblioteke Srbije v Beogradu.

\section{0}

\section{Ocene, poročila}

Međunarodni susret mladih umetnika u Bayreuthu. Zvuk 1960, 41-42, 80-83. Podpis: Marija Koren.

\section{1}

\section{Zapisi razprav}

Prvi muzički biennale u Zagrebu. Pogledi i utisci. Zapis razprave. Zvuk 1961, 49-50, 480-512. Marija Bergamo: Stravična razpoloženja u novoj muzici, str. 490. Podpis: Marija Koren. 


\section{2}

\section{Ocene, poročila}

Bruno Walter. Zvuk 1962, 53, 348-350. Podpis: M. K.

Smrt Ninon Vallin. Zvuk 1962, 53, 359-360. Podpis na koncu rubrike: M. K. Rubrika: Kroz štampu i događaje.

Picasso i muzika. Zvuk 1962, 53, 360-361. Podpis na koncu rubrike: M. K. Rubrika: Kroz štampu i događaje.

Lečenje hiperprodukcije pijanista. Zvuk 1962, 53, 361. Podpis na koncu rubrike: M. K. Rubrika: Kroz štampu i događaje.

Više ukusa u opremi gramofonskih ploča. Zvuk 1962, 53, 361-362. Podpis na koncu rubrike: M. K. Rubrika: Kroz štampu i događaje.

Šta je to orkestar? Zvuk 1962, 54, 487. Podpis na koncu rubrike: M. K. Rubrika: Kroz štampu i događaje.

Nepoznati Paganinijev testament. Zvuk 1962, 54, 487-488. Podpis na koncu rubrike: M.

K. Rubrika: Kroz štampu i događaje.

Elektronski instrumenti u crkvi. Zvuk 1962, 54, 488. Podpis na koncu rubrike: M. K. Rubrika: Kroz štampu i događaje.

Koliko je sonata napisao Beethoven? Zvuk 1962, 54, 488. Podpis na koncu rubrike: M. K. Rubrika: Kroz štampu i događaje.

Moderna viola d'amore. Zvuk 1962, 54, 488-489. Podpis na koncu rubrike: M. K. Rubrika: Kroz štampu i događaje.

Smrt Fritza Kreislera. Zvuk 1962, 54, 489. Podpis na koncu rubrike: M. K. Rubrika: Kroz štampu i događaje.

\section{3}

\section{Ocene, poročila}

Novootkrivena Vivaldijeva dela. Zvuk 1963, 56, 123-124. Podpis na str. 125: M. K. Rubrika: Kroz štampu i događaje.

Izložba starih instrumenata. Zvuk 1963, 56, 124. Podpis na str. 125: M. K. Rubrika: Kroz štampu i događaje.

Muzičke svečanosti u Wiesbadenu. Zvuk 1963, 56, 124-125. Podpis na str. 125: M. K. Rubrika: Kroz štampu i događaje.

Händelove svečanosti u Halleu. Zvuk 1963, 56, 125. Podpis na str. 125: M. K. Rubrika: Kroz štampu i događaje.

Monteverdijeva nedelja u Wuppertalu. Zvuk 1963, 56, 125. Podpis na str. 125: M. K. Rubrika: Kroz štampu i događaje.

Uspeh zagrebačke opere u Berlinu. Zvuk 1963, 56, 125. Podpis na str. 125: M. K. Rubrika: Kroz štampu i događaje.

Pejović Roksanda: Istorija muzike (Barok - Rokoko - Klasika) Beograd, 1962. (183 strane). Zvuk 1963, 57, 295-296. Podpis: M. K.

Otkrivena spomen ploča kompozitorima palim borcima. Zvuk 1963, 57, 299. Podpis na str. 304: M. K. Rubrika: Kroz štampu i događaje. 
Zofia Lissa u Jugoslaviji. Zvuk 1963, 57, 299-300. Podpis na str. 304: M. K. Rubrika: Kroz štampu i događaje.

Obnova varšavskog operskog pozorišta. Zvuk 1963, 57, 300-301. Podpis na str. 304: M. K. Rubrika: Kroz štampu i događaje.

Kongres folklorista u Berlinu. Zvuk 1963, 57, 301. Podpis na str. 304: M. K. Rubrika: Kroz štampu i događaje.

100 [Sto] godina lenjingradskog konzervatorijuma. Zvuk 1963, 57, 301. Podpis na str. 304: M. K. Rubrika: Kroz štampu i događaje.

Prepiska između R. Straussa i R. Rollanda. Zvuk 1963, 57, 301-302. Podpis na str. 304: M. K. Rubrika: Kroz štampu i događaje.

Problem mladih virtuoza. Zvuk 1963, 57, 302-303. Podpis na str. 304: M. K. Rubrika: Kroz štampu i događaje.

Orffov metod muzičkog vaspitanja dece. Zvuk 1963, 57, 303. Podpis na str. 304: M. K. Rubrika: Kroz štampu i događaje.

Maeterlinck i kompozitori. Zvuk 1963, 57, 303-304. Podpis na str. 304: M. K. Rubrika: Kroz štampu i događaje.

Jubilej Zoje Mihailovne Gajdaj. Zvuk 1963, 57, 304. Podpis na str. 304: M. K. Rubrika: Kroz štampu i događaje.

Nikola Hercigonja, Đorđe Karaklajić: Zbornik partizanskih narodnih napeva. Nolit, Beograd 1962. Zvuk 1963, 58, 438-439. Podpis: M. K.

Nova katedra za muzikologiju u Ljubljani. Zvuk 1963, 58, 463-464. Podpis na str. 466: M. K. Rubrika: Kroz štampu i događaje.

»Tri nedelje u Jugoslaviji«. Zvuk 1963, 58, 464. Podpis na str. 466: M. K. Rubrika: Kroz štampu i događaje.

Opštu istoriju muzike treba ispraviti. Zvuk 1963, 58, 464. Podpis na str. 466: M. K. Rubrika: Kroz štampu i događaje.

Film i elektronska muzika. Zvuk 1963, 58, 464-465. Podpis na str. 466: M. K. Rubrika: Kroz štampu i događaje.

Iz prve ruke. Zvuk 1963, 58, 465. Podpis na str. 466: M. K. Rubrika: Kroz štampu i događaje.

Zbirka muzikalija u češkom zamku. Zvuk 1963, 58, 465. Podpis na str. 466: M. K. Rubrika: Kroz štampu i događaje.

Tehnizacija kulture ili kultivizacija tehnike? Zvuk 1963, 58, 465. Podpis na str. 466: M. K. Rubrika: Kroz štampu i događaje.

Postoje li nemuzikalni ljudi? Zvuk 1963, 58, 465. Podpis na str. 466: M. K. Rubrika: Kroz štampu i događaje.

Novo Bachovo društvo. Zvuk 1963, 58, 466. Podpis na str. 466: M. K. Rubrika: Kroz štampu i događaje.

Prvi susret sa publikom Sovjetskog saveza. Zvuk 1963, 60, 706-709. Podpis: Marija Koren.

\section{4}

\section{Ocene, poročila}

Uspjelo veče. Pina Karmireli s Beogradskom filharmonijom. Dirigent Živojin Zdravković - Beograd, 14. IV 1964. Borba 29/1964 (16.4.), 105, 7. Podpis: Marija Koren. 
Veče Čajkovskog. Zlatko Topolski s Beogradskom filharmonijom. Dirigent Živojin Zdravković. Beograd, 21. aprila 1964. Borba 29/1964 (23.4.), 112, 7. Podpis: Marija Koren. Veliki umjetnički doživljaj. Koncert Slovenskog vokalnog okteta, 22. aprila 1964, Dvorana KNU. Borba 29/1964 (24.4.), 113, 7. Podpis: M. Koren.

Stjepan Šulek: »Peta simfonija». Koncert Beogradske filharmonije - dirigent Stjepan Šulek - solist Ljubinka Kostović. Borba 29/1964 (30.4.), 118, ?. Podpis: Marija Koren. Beograjska izdaja. - Cirilica. - Popisano po: Bibliografija Jugoslavije 1964, 3-4, 287 in 288 .

Lijepa i pohvalna tradicija. Komorni koncert Udruženja kompozitora Srbije, Dvorana radničkog univerziteta »Đuro Salaj«, Beograd, 6. maja. Borba 29/1964 (9.5.), 126, 7. Podpis: Marija Koren. Zagrebška izdaja.

Poneseno muziciranje. Koncert Beogradske filharmonije. Solisti T. Đurova i M. Stefanović. Dirigent dr Oskar Danon. Beograd, 13. V 1964. Borba 29/1964 (15.5.), 132, 7. Podpis: Marija Koren.

Koncert Zagrebačke filharmonije - dirigent Milan Horvat - solisti Zorica Dimitrijević - Vladimir Krpan. Borba 29/1964 (28.5.), 144, ?. Podpis: Marija Koren. Beograjska izdaja. - Cirilica. - Popisano po: Bibliografija Jugoslavije 1964, 5-6, 583.

Majstorstvo Ruđera Ričija. Koncert američkog violinista Ruđera Ričija. Dvorana radničkog univerziteta "Đuro Salaj« u Beogradu. Borba 29/1964 (26.9.), 266, 7. Podpis: Marija Koren. Zagrebška izdaja.

Koncert Beogradske filharmonije - dirigent Živojin Zdravković. Borba 29/1964 (11.10.), 280, ?. Podpis: Marija Koren. Beograjska izdaja. - Cirilica. - Popisano po: Bibliografija Jugoslavije 1964, 7-8, 884.

Recital: Kioko Tanaka. Klavirski solistički koncert. Kolarčev narodni univerzitet. 12. X 1964, Beograd. Borba 29/1964 (15.10.), 284, 7. Podpis: Marija Koren. Zagrebška izdaja.

Vokalni recital Ljiljane Molnar. Borba 29/1964 (17.10.), 286, ? Podpis: Marija Koren. Beograjska izdaja. - Cirilica. - Popisano po: Bibliografija Jugoslavije 1964, 9-10, 1060.

Poznanstvo sa Luz Vernon. Solistički koncert u dvorani radničkog univerziteta »Đuro Salaj«, Beograd, 4. XI 1964. Borba 29/1964 (7.11.), 307, 7. Podpis: Marija Koren.

Veče gudačkih kvarteta. Koncert studenata Visoke škole za muziku u Kelnu, sala radničkog univerziteta »Đuro Salaj«, 11. novembra 1964 godine. Borba 29/1964 (14.11.), 314, 7. Podpis: Marija Koren.

Zanimljiv susret s filharmoničarima iz [Kl]uža. Simfonijski koncert Državne filharmonije iz Kluža, dirigent Emil Simon, solist Stefan Ruha. Kolarčev narodni univerzitet, 17. XI 1964 godine. Borba 29/1964 (20.11.), 320, 7 (*** in **** izdaja). Podpis: Marija Koren.

Veliki majstor klavira Nikita Magalov. Solistički koncert u dvorani Kolarčevog narodnog univerziteta. Beograd, 19. XI 1964. Borba 29/1964 (25.11.), 325, 7. Podpis: Marija Koren. Zagrebška izdaja.

Jubilarni koncert muzičke škole »Mokranjac«. Jubilarni koncert solista škole uz suradnju Beogradske filharmonije, dirigent Ž. Zdravković, Beograd 24. XI 1964. Borba 29/1964 (27.11.), 327, 7. Podpis: Marija Koren.

Profinjena stilska kultura. Solistički koncert mezosoprana Julijane Anastasijević, Kolarčev narodni univerzitet, 3. XII 1964. Borba 29/1964 (8.12.), 336, 17 (Zagrebačko izdanje). Podpis: Marija Koren. Zagrebška izdaja. 
Visok nivo zborskog muziciranja. Koncert Zbora i Simfonijskog orkestra Radio-televizije Beograd, dirigent Borivoje Simić, Kolarčev narodni univerzitet, 7. decembar 1964. Borba 29/1964 (10.12.), 338, 12. Podpis: Marija Koren.

Bramsova Četvrta - veliko ostvarenje Beogradske filharmonije. Svečani koncert u čast Osmog kongresa Saveza komunista Jugoslavije u okviru Muzičke omladine, Beogradska filharmonija, dirigent Živojin Zdravković, solist Zorica Mihajlović, Kolarčev narodni univerzitet. Borba 29/1964 (15.12.), 343, 8. Podpis: Marija Koren.

Jedno uspjelo tumačenje Mocarta. Simfonijski koncert Beogradske filharmonije, dirigent Pjer Mišel le Kont (Pariz), solist Branko Pajević. Kolarčev narodni univerzitet. Borba 29/1964 (15.12.), 343, 8. Podpis: Marija Koren.

Nagradno takmičenje amaterskih zborova Jugoslavije. Povodom proslave 50-godišnjice smrti Stevana Mokranjca, Kolarčev narodni univerzitet 12, 13. i 14. decembra 1964. Borba 29/1964 (17.12.), 345, 7. Podpis: Marija Koren. Zagrebška izdaja.

\section{5}

\section{Ocene, poročila}

Gostovanje Igora Đadrova. Koncert Beogradske filharmonije za Muzičku omladinu Beograda. Dirigent Igor Đadrov, solist Aleksandar Pavlović. Borba 30/1965 (5.1.), 3, 7. Podpis: Marija Koren.

Faust Mikelea Molezea. Gostovanje Mikelea Molezea (Milano) u operi »Faust« u Narodnom pozorištu u Beogradu, 11. I. 1965. Borba 30/1965 (13.1.), 11, 7. Podpis: Marija Koren. Zagrebška izdaja.

Koncert dečjeg simfonijskog orkestra iz Sofije - dirigent Vladi Simeonov. Borba 30/1965 (15.1.), 13, ? Podpis: Marija Koren. Beograjska izdaja. - Cirilica. - Popisano po: Bibliografija Jugoslavije 1965, 1-2, 15.

Recital Valentina Georgiua. Klavirski solistički koncert Valentina Georgiua, Kolarčev narodni univerzitet, Beograd, 14. januara 1965. Borba 30/1965 (20.1.), 18, 7. Podpis: Marija Koren.

Koncert solista Beogradske filharmonije. Borba 30/1965 (23.1.), 21, ?. Podpis: Marija Koren. Beograjska izdaja. - Cirilica. - Popisano po: Bibliografija Jugoslavije 1965, 1-2, 17.

Umjetnost Pavice Gvozdić. Solistički koncert Pavice Gvozdić na Kolarčevom narodnom univerzitetu. Beograd, 21. januara. Borba 30/1965 (26.1.), 24, 9. Podpis: Marija Koren.

Recital Františeka Maksijana. Solistički klavirski koncert F. Maksijana (Čehoslovačka). Velika dvorana Doma sindikata, Beograd, 28. I. Borba 30/1965 (2.2.), 31, 7. Podpis: Marija Koren.

Napor nepotpuno krunisan rezultatom. Đuzepe Verdi: „Moć sudbine« na sceni opere Narodnog pozorišta u Beogradu, dirigent Dušan Miladinović. Borba 30/1965 (10.2.), 39, 7. Podpis: Marija Koren.

Koncert Milenka Stefanovića. Borba 30/1965 (13.2.), 42, ? Podpis: Marija Koren. Beograjska izdaja. - Cirilica. - Popisano po: Bibliografija Jugoslavije 1965, 1-2, 16.

Umjetnost komornog ansambla iz Firence. Koncert komornog orkestra Palate piti iz Firence: Dirigent Aldo Faldi, Kolarčev narodni univerzitet, 20. februara 1965. godine. Borba 30/1965 (23.2.), 52, 7. Podpis: Marija Koren. 
Koncert Kamernog dua Milan Bauer - Mihal Karin. Borba 30/1965 (27.2.), 56, ?. Podpis: Marija Koren. Beograjska izdaja. - Cirilica. - Popisano po: Bibliografija Jugoslavije 1965, 1-2, 16.

Koncert Simfonijskog orkestra Doma JNA - dirigent Franc Klinar - solist Đuka Tonči - Tripo Simonuti - Srđan Grbić. Borba 30/1965 (16.3.), 73, ?. Podpis: Marija Koren. Beograjska izdaja. - Cirilica. - Popisano po: Bibliografija Jugoslavije 1965, 3-4, 196. Vokalni recital Dušana Jankovića. Radnički univerzitet Đuro Salaj, 15. mart 1965. Borba 30/1965 (17.3.), 74, 7. Podpis: M. Koren. Zagrebška izdaja.

Bez dubljeg umjetničkog doživljaja. Simfonijski koncert Beogradske filharmonije. Dirigent Luis Herera de la Fuente, solist Olga Jovanović, Kolarčev narodni univerzitet, 16. III 1965. Borba 30/1965 (18.3.), 75, 9. Podpis: Marija Koren.

Koncert Duvačkog orkestra Beogradskog garnizona - dirigent Vinko Savnik - solista Olivera Đurđević. Borba 30/1965 (23.3.), 80, ?. Podpis: Marija Koren. Beograjska izdaja. - Cirilica. - Popisano po: Bibliografija Jugoslavije 1965, 5-6, 383.

Koncert Simfonijskog orkestra Doma JNA - dirigent Ekard Hansen - solist Radmila Bakočević - Jiři Hubička. Borba 30/1965 (24.3.), 81, ?. Podpis: Marija Koren. Beograjska izdaja. - Cirilica. - Popisano po: Bibliografija Jugoslavije 1965, 3-4, 195.

Veče nordijske muzike. Simfonijski orkestar Doma JNA. Dirigent Ekard Hansen (Kopenhagen). Solisti Radmila Bakočević i Jirži Hubička (Prag). Kolarčev narodni univerzitet, 20. III. Borba 30/1965 (25.3.), 82, 7. Podpis: Marija Koren. Zagrebška izdaja.

Koncert za orkestar Petra Ozgijana. Simfonijski koncert Beogradske filharmonije. Dirigent Dušan Skovran, solista Marina Mdivani (SSSR). Kolarčev narodni univerzitet (23. mart 1965.). Borba 30/1965 (26.3.), 83, 7. Podpis: Marija Koren.

Susret s bugarskim umjetnicima. Koncert bugarske suvremene muzike u izvedbi M. Nikolove, N. Evrova i B. Lečeva (NR Bugarska). Radnički univerzitet »Đuro Salaj«, 1. aprila 1965. Borba 30/1965 (6.4.), 94, 7. Podpis: Marija Koren.

Visok umjetnički domet. Gostovanje Zagrebačke filharmonije pod vodstvom dr Milana Horvata. Solist Franko Guli, Italija. Kolarčev narodni univerzitet, Beograd, 15. IV 1965. Borba 30/1965 (20.4.), 108, 7. Podpis: Marija Koren.

Praznik belkanta. Gostovanje talijanskih umjetnika u Rosinijevom »Seviljskom brijaču«. Narodno pozorište, Beograd, 18. IV 1965. Borba 30/1965 (20.4.), 108, 7. Podpis: Marija Koren. Zagrebška izdaja.

Koncert Muzičke akademije. Koncert solista i orkestra Muzičke akademije u Beogradu. Dirigent Dušan Skovran. Beograd, Kolarčev narodni univerzitet, 19. IV 1965. Borba 30/1965 (22.4.), 110, 7. Podpis: Marija Koren.

Koncert Jovana Kolundžije. Borba 30/1965 (30.4.), 118, ?. Podpis: Marija Koren. Beograjska izdaja. - Cirilica. - Popisano po: Bibliografija Jugoslavije 1965, 3-4, 195.

Četiri čarobnjaka. Koncert američkog kvarteta La Sale, Komorna pozornica Studentskog centra, 13. V 1965. Borba 30/1965 (15.5.), 131, 7. Podpis: Marija Koren. Zagrebška izdaja.

Češki nonet. Studentski centar, 14. V 1965. Borba 30/1965 (16.5.), 132, 10. Podpis: Marija Koren. Zagrebška izdaja.

Mesijan - sinteza francuske muzike. Simfonijski koncert Beogradske filharmonije, dirigent Ž. Zdravković, solisti O. Jovanović, Y. Loriod i J. Loriod. »Istra«14. V 1965. Borba 30/1965 (16.5.), 132, 10. Podpis: Marija Koren. 
Konvecionalno, neinventivno. Komorni program I. Izvođači: Duhački trio Salcburškog komornog društva, A. Landrot, oboa, H. Leuthold, klarinet, R. Klepač, fagot, H. Zangerle, flauta, H. Radhuber, čembalo, R. Pospiš, alt, komorni sastav. Dirigent Igor Đadrov. Studentski centar 15. V 1965. Borba 30/1965 (18.5.), 134, 7. Podpis: Marija Koren.

Blistav početak sezone. Hajdnov oratorij »Godišnja doba u u izvođenju solista, zbora i orkestra Opere Narodnog pozorišta u Beogradu. Dirigent Dušan Miladinović. Kolarčev narodni univerzitet, 3. oktobra 1965. Borba 30/1965 (6.10.), 275, 7. Podpis: Marija Koren. Zagrebška izdaja.

Uzdržano is mjerom. Gostovanje simfonijskog orkestra Radio Frankfurta, dirigent Dik Dikson, Beograd, 14. oktobra 1965. Borba 30/1965 (19.10.), 288, 7. Podpis: Marija Koren. Zagrebška izdaja.

Umjetnost Isaka Šterna. Violinski solistički koncert Isaka Šterna (SAD), Dvorana Kolarčevog narodnog univerziteta, 29. oktobra 1965. Borba 30/1965 (2.11.), 302, 7. Podpis: Marija Koren.

Šumanovo veče. Solistički klavirski koncert Branka Sepčića, Zagreb. Kolarčev narodni univerzitet, 1. novembar 1965, Beograd. Borba 30/1965 (4.11.), 304, 7. Podpis: Marija Koren. Zagrebška izdaja.

Majstor na orguljama. Koncert na orguljama Johanesa Ernsta Kelera (Vajmer), Velika dvorana Doma sindikata, 4. novembra 1965. Borba 30/1965 (6.11.), 306, 7. Podpis: Marija Koren.

Bramsovo veče Beogradske filharmonije. Simfonijski koncert Beogradske filharmonije, dirigent Ž. Zdravković, solist Andre de Grot, klavir (Belgija). Kolarčev narodni univerzitet, Beograd, 12. XI 1965. Borba 30/1965 (16.11.), 316, 7. Podpis: Marija Koren.

Uspjelo veče Beogradske filharmonije. Abonentski koncert Beogradske filharmonije, dirigent Dušan Skovran, solist Barbara Hese-Bukovska, klavir (Poljska). Kolarčev narodni univerzitet. Borba 30/1965 (2.12.), 330, 7. Podpis: Marija Koren.

Jubilej Marije Mihailović. Svečani koncert povodom 40-godišnjice umjetničkog rada violinistkinje Marije Mihailović. Orkestar Beogradske filharmonije, dirigent Đura Jakšić. Kolarčev narodni univerzitet, 17. december 1965. Borba 30/1965 (21.12.), 349, 7. Podpis: Marija Koren. Zagrebška izdaja.

Koncert Beogradske filharmonije - dirigent Đura Jakšić - solista Marija Mihailović. Borba 30/1965 (22.12.), 350, ? Podpis: Marija Koren. Beograjska izdaja. - Cirilica. - Popisano po: Bibliografija Jugoslavije 1965, 11-12, 895.

Od anonimnosti do međunarodne afirmacije. Proslava 20-godišnjice osnivanja Udruženja kompozitora Srbije, lijepo organizirana, obuhvatila je u toku tjedan dana dva simfonijska i dva komorna koncerta, magnetofonski koncert umjetničkih obrada narodnih pjesama i plesova, koncert zabavne muzike i koncert duhačkog orkestra Beogradskog garnizona, uz uvodni svečani plenum s predajom diploma-zahvalnica istaknutim muzičkim umjetnicima i svečanom akademijom s otvaranjem izložbe posvećene radu članova Udruženja i predajom spomen-skulptura članovima inicijativnog odbora iz 1945. godine i plaketa svim bivšim predsjednicima Udruženja. Borba 30/1965 (26.12.), 354, 10. Podpis: Marija Koren.

\section{6}

\section{Članki}

Mirjana Živković. Mladi kompozitor. Pro musica 1966, 16-17, 17. Podpis: Marija Koren. Cirilica. 
Naša mišljenja. [Uvodnik]. Pro musica 1966, 19, 1, 48. Brez podpisa. Avtorstvo na podlagi registra imen, Pro musica 1971, 1-50, str. 15. - Cirilica.

Rajko Maksimović. Mladi kompozitor. Pro musica 1966, 19, 34. Podpis: M. K. Cirilica. Simfonija u stvaralačkom opusu Milana Ristića. Povodom IV simfonije. Zvuk 1966, 69, 494-504. Podpis: Marija Koren.

\section{Ocene, poročila}

Bramsovo veče Stjepana Šuleka. Simfonijski koncert Beogradske filharmonije, dirigent Stjepan Šulek (Zagreb). Kolarčev narodni univerzitet, Beograd, 28. XII 1965. Borba 31/1966 (8.1.), 6, 7. Podpis: Marija Koren.

Nova kantata Nikole Hercigonje. Simfonijski koncert Umjetničkog ansambla Doma JNA. Dirigent: Živojin Zdravković. Solisti: O. Jovanović, M. Stupica, D. Nikolić, J. Miličević, I. Bulajić, N. Knežević. Kolarčev narodni univerzitet, Beograd, 19. I 1966. Borba 31/1966 (29.1.), 27, 7. Podpis: Marija Koren. Zagrebška izdaja.

Trenutak naše prošlosti. Simfonijski koncert Beogradske filharmonije. Dirigent Đura Jakšić. Solisti Andreja Preger, klavir i Stjepan Rabuzin, horna. Kolarčev narodni univerzitet, 28. januar 1966. Borba 31/1966 (1.2.), 30, 7. Podpis: Marija Koren.

Skladnost forme i sadržaja. Simfonijski koncert Beogradske filharmonije, dirigent Robert Vagner (Austrija). Solisti Vladimir Marković, violina i Marčelo Vjecoli (Italija), violončelo. Beograd, Kolarčev narodni univerzitet, 4. februara 1966. Borba 31/1966 (8.2.), 37, 7. Podpis: Marija Koren. Blistav početak. Solistički klavirski koncert Božene Bogosavljević. Beograd, Kolarčev narodni univerzitet, 15. februara 1966. Borba 31/1966 (18.2.), 47, 7. Podpis: Marija Koren.

Merdžori Mičel. Borba 31/1966 (23.2.), 52, ?. Podpis: Marija Koren. Beograjska izdaja.

- Cirilica. - Popisano po: Bibliografija Jugoslavije 1966, 1-2, 19.

Tripo Simonuti. Borba 31/1966 (23.2.), 52, ?. Podpis: Marija Koren. Beograjska izdaja.

- Cirilica. - Popisano po: Bibliografija Jugoslavije 1966, 1-2, 19.

Nesklad zamisli i ostvarenja. Solistički koncert Milice Popović, soprana. Za klavirom Zoran Jovanović. Dvorana radničkog univerziteta »Đuro Salaj«, Beograd. Borba 31/1966 (26.2.), 55, 9. Podpis: M. Koren. Zagrebška izdaja.

Ansambl majstora. Koncert duhačkog kvinteta Beogradske filharmonije. Beograd, Kolarčev narodni univerzitet, 28. februar 1966. Borba 31/1966 (3.3.), 60, 7. Podpis: Marija Koren.

Koncert Slovenske filharmonije. Dirigent Samo Hubad - solist Pavica Gvozdić. Borba 31/1966 (11.3.), 68, ? Podpis: Marija Koren. Beograjska izdaja. - Cirilica. - Popisano po: Bibliografija Jugoslavije 1966, 3-4, 214.

Betovenovo veče. Koncert Beogradskog komornog trija: A. Preger, klavir, A. Pavlović - violina, V. Jakovčić - violončelo, uz suradnju Đ. Čakarević - mecosopran. Kolarčev narodni univerzitet, Beograd, 10. III 1966. Borba 31/1966 (12.3.), 69, 9. Podpis: Marija Koren. Zagrebška izdaja.

Standardna rješenja. »Oklahoma« R. Rodžersa i G. Hamerštajna na terazijskoj sceni Suvremenog pozorišta. Borba 31/1966 (15.3.), 72, 7. Podpis: Marija Koren.

Johann Strauss: »Slepi miš«. Borba 31/1966 (16.3.), 73, ?. Podpis: Marija Koren. Beograjska izdaja. - Cirilica. - Popisano po: Bibliografija Jugoslavije 1966, 3-4, 211.

Betoven za mlade. Simfonijski koncert Beogradske filharmonije. Dirigent Đ. Jakšić. Solist R. Miodragović - klavir. Kolarčev narodni univerzitet, Beograd. Borba 31/1966 (17.3.), 74, 7. Podpis: M. Koren. 
Samo napor. Simfinijski koncert Beogradske filharmonije posvećen djelima Johana i Jozefa Štrausa. Dirigent Eduard Štraus (Beč). Kolarčev narodni univerzitet. Borba 31/1966 (17.3.), 74, 7. Podpis: Marija Koren.

Ponovni susret s Mladenom Jaguštom. Simfonijski koncert Beogradske filharmonije. Dirigent Mladen Jagušt. Solisti: Ljubinka Kostović, klavir i Božidar Tumpej, fagot. Beograd, Kolarčev narodni univerzitet 22. III 1966. Borba 31/1966 (26.3.), 83, 7. Podpis: M. Koren. Zagrebška izdaja.

Ozbiljni izvođački rezultati. Koncert zbora i orkestra Muzičke akademije, dirigent V. Ilić, čembalo O. Đurđević, solist O. Hirjovatij. Beograd, Kolarčev narodni univerzitet, 6. IV 1966. Borba 31/1966 (9.4.), 97, 7. Podpis: M. Koren. Zagrebška izdaja.

Orguljska večer Gabora Lehotke. Koncert na orguljama Gabora L[e]hotke, Budimpešta. Dvorana Doma sindikata, 18. aprila 1966. Borba 31/1966 (21.4.), 109, 7. Podpis: M. K. Zagrebška izdaja.

Gabor Lehotka. Borba 31/1966 (22.4.), 110, ?. Podpis: Marija Koren. Beograjska izdaja. - Cirilica. - Popisano po: Bibliografija Jugoslavije 1966, 3-4, 212.

Prefinjenost i kultura. Klavirski solistički koncert Erika Houpa, London. Kolarčev narodni univerzitet. Borba 31/1966 (26.4.), 114, 7. Podpis: Marija Koren.

Četiri čarobnjaka. Koncert Zagrebačkog gudačkog kvarteta (J. Klima, Z. Balija, D. Stranić, J. Stojanović), Kolarčev narodni univerzitet, 9. maja 1966. Borba 31/1966 (11.5.), 127, 7. Podpis: Marija Koren. Zagrebška izdaja.

Betovenovo veče Beogradske filharmonije. Simfonijski koncert Beogradske filharmonije, dirigent Oskar Danon, solist Branko Pajević - violina. Borba 31/1966 (12.5.), 128, 7. Podpis: Marija Koren.

Kvalitetno orkestarsko muziciranje. Koncert orkestra Muzičke akademije. Dirigent Dušan Skovran. Kolarčev narodni univerzitet. Borba 31/1966 (8.6.), 155, 11. Podpis: Marija Koren. Zagrebška izdaja.

Gosti iz Poljske. Koncert orkestra muzičkog liceja »F. Šopen« iz Krakova, dirigent Irena Pfeifer. Kolarčev narodni univerzitet. Borba 31/1966 (8.6.), 155, 11. Podpis: M. Koren. Zagrebška izdaja.

Ruža Pospiš na sceni Beogradske opere. Borba 31/1966 (8.6.), 155, 11. Brez podpisa. Zagrebška izdaja.

Rijedak umjetnički doživljaj. Koncert komornog orkestra Moskovskog državnog konzervatorija »Petar Ilijič Čajkovski«, dirigent prof. Mihail Terijan. Kolarčev narodni univerzitet. Borba 31/1966 (10.6.), 157, 8. Podpis: Marija Koren.

U znaku »Labuda iz Pezara». Simfonijski koncert Beogradske filharmonije, dirigent B. Babić, solisti R. Tudor, R. Bakočević, Đ. Čakarević, Z. Krnetić, Đ. Đurđević. Uz suradnju mješovitog zbora »Branko Krsmanović«. Kolarčev narodni univerzitet. Borba 31/1966 (11.6.), 158, 8. Podpis: Marija Koren. Zagrebška izdaja.

Obnovljena »Aida« na sceni Beogradske opere. (Narodno pozorište u Beogradu - dirigent Bogdan Babić, redatelj Ani Radošević, scenograf Vladimir Marenić, kostimograf Ljiljana Dragović, koreograf Vera Kostić, 21. septembra 1966.) Borba 31/1966 (23.9.), 262, 9. Podpis: Marija Koren.

Odličan zborski ansambl. Koncert mješovitog zbora AKUD »Slobodan Princip Seljo« iz Sarajeva. Dirigent Miroslav Homen. Beograd, Kolarčev narodni univerzitet, 28. IX 1966. Borba 31/1966 (1.10.), 270, 9. Podpis: Marija Koren. Zagrebška izdaja. 
Koncert Jošio Uno. Borba 31/1966 (13.10.), 282, ? Podpis: Marija Koren. Beograjska izdaja.

- Cirilica. - Popisano po: Bibliografija Jugoslavije 1966, 9-10, 774.

Beogradska filharmonija za mlade. Simfonijski koncert Beogradske filharmonije za Muzičku omladinu. Dirigent Samo Hubad, solisti Sretna Pavičić, klavir, Milica Barić, harfa i Aleksandar Isaković, violina. Kolarčev narodni univerzitet. Borba 31/1966 (19.10.), 288, 7. Podpis: Marija Koren. Zagrebška izdaja.

Veliki mag klavira. Još jedan susret s Arturom Rubinštajnom. Borba 31/1966 (30.10.), 299, 11. Podpis: Marija Koren. Zagrebška izdaja.

Neprikladan izbor djela. Simfonijski koncert Beogradske filharmonije, dirigent Dušan Miladinović i Koncert akademskog zbora Moskovskog državnog univerziteta M. V. Lomonosova, dirigent C. V. Popov i B. V. Baranov. Borba 31/1966 (9.11.), 309, 7. Podpis: Marija Koren. Zagrebška izdaja.

Prvi pravi festival jugoslavenske muzike. Borba 31/1966 (13.11.), 313, 9. Podpis: Marija Koren. Prvi festival jugoslavenske muzike na radiu, 7.-10.11.1966, organizator Jugoslavenska radiotelevizija, realizacija Radio Beograd. - Zagrebška izdaja.

Hladni sjaj njemačke klasike. Simfonijski koncert Beogradske filharmonije. Dirigent Hans Miler Kraj SR Njemačka. Solisti M. Vukdragović - Lojović, D. Mihailović - Pavlović, J. Srejović, Kolarčev narodni univerzitet. Borba 31/1966 (15.12.), 34[3], 7 (*** in **** izdaja). Podpis: Marija Koren.

Lijepa inicijativa. Solistički koncert Miloša Jurkoviča, flauta i Ludovita Marcingera, klavir (Bratislava). Radnički univerzitet »Đuro Salaj«, 14. XII 1966. Borba 31/1966 (17.12.), 345, 7 (*** in *** izdaja). Podpis: Marija Koren. Zagrebška izdaja.

Recital Petra Toškova. Violinski solistički koncert Petra Toškova, za kl[a]virom Zorica Dimitrijević. Beograd, Kolarčev narodni univerzitet. Borba 31/1966 (24.12.), 352, 7. Podpis: Marija Koren. Zagrebška izdaja.

Ugodno iznenađenje. Koncert novoosnovanog Beogradskog kamernog ansambla,

dirigent Pavle Dešpalj. Dom omladine, Beograd 15. decembar 1966. Borba 31/1966 (24.12.), 352, 7 (*** in *** izdaja). Podpis: Marija Koren. Zagrebška izdaja.

Simfonijski koncert Umetničkog ansambla doma JNA. Dirigent Živojin Zdravković. Pro musica 1966, 13, 23. Podpis: Marija Koren. Rubrika: U koncertnim dvoranama. - Cirilica. Simfonijski koncert Beogradske filharmonije. Solist Mirjana Vukdragović. Pro musica 1966, 13, 23. Podpis: Marija Koren. Rubrika: U koncertnim dvoranama. - Cirilica.

Simfonijski koncert Beogradske filharmonije. Dirigent Stjepan Šulek. Pro musica 1966, 13, 23. Podpis: Marija Koren. Rubrika: U koncertnim dvoranama. - Cirilica.

Simfonijski koncert Beogradske filharmonije. Dirigent Đura Jakšić. Pro musica 1966, 13 , 23. Podpis: Marija Koren. Rubrika: U koncertnim dvoranama. - Cirilica.

Gostovanje Slovenske filharmonije. Pro musica 1966, 15, 38. Podpis: Marija Koren. Rubrika: U koncertnim dvoranama. - Cirilica.

Koncert Beogradskog kamernog trija. Pro musica 1966, 15, 38. Podpis: Marija Koren. Rubrika: U koncertnim dvoranama. - Cirilica.

Betoven za mlade. Pro musica 1966, 15, 38. Podpis: Marija Koren. Rubrika: U koncertnim dvoranama. - Cirilica.

Ponovni susret sa Mladenom Jaguštom. Pro musica 1966, 15, 38. Podpis: Marija Koren. Rubrika: U koncertnim dvoranama. - Cirilica. 
Koncert hora i orkestra Muzičke akademije. Pro musica 1966, 15, 38. Podpis: Marija Koren. Rubrika: U koncertnim dvoranama. - Cirilica.

M. Hauer - operski kompozitor. Zvuk 1966, 69, 590. Podpis na str. 591: M. Koren. Rubrika: Kroz štampu i događaje.

Mahlerova deseta simfonija. Zvuk 1966, 69, 590. Podpis na str. 591: M. Koren. Rubrika: Kroz štampu i događaje.

Smrt Edgara Varesea. Zvuk 1966, 69, 591. Podpis na str. 591: M. Koren. Rubrika: Kroz štampu i događaje.

Grčke vaze kao rezonatori. Zvuk 1966, 69, 591. Podpis na str. 591: M. Koren. Rubrika: Kroz štampu i događaje.

Opera J. Chr. Bacha. Zvuk 1966, 69, 591. Podpis na str. 591: M. Koren. Rubrika: Kroz štampu i događaje.

Premijera Henzeove opere Die Bassariden. Zvuk 1966, 70, 767. Podpis na str. 768: M. K. Rubrika: Kroz štampu i događaje.

Otvaranje nove zgrade Metropolitena. Zvuk 1966, 70, 767-768. Podpis na str. 768: M. K. Rubrika: Kroz štampu i događaje.

Händelova Agripina sa plejbojima, penušavim kupatilom i modnom revijom. Zvuk 1966, 70, 768. Podpis na str. 768: M. K. Rubrika: Kroz štampu i događaje.

Umetnički trijumf Pierrea Bouleza. Zvuk 1966, 70, 768. Podpis na str. 768: M. K. Rubrika: Kroz štampu i događaje.

\section{Prevodi}

Evžen Valovy: Problemi intonacije suvremenog vokalnog stvaralaštva. Sa češkog prevela M[arija] K[oren]. Muzika i škola 11/1966, 1, 11-16.

\section{7}

\section{Članki}

Muzičke škole u SSSR-u. Pro musica 1967, 22, 16. Podpis: Marija Koren. Cirilica.

100 [Sto] godina moskovskog konzervatorijuma. Pro musica 1967, 23, 14, 43. Podpis: Marija Koren. Cirilica.

\section{Ocene, poročila}

Simfonija Vasilija Mokranjca. Simfonijski koncert beogradske filharmonije, dirigent Dušan Skovran, solista Olga Sevkenova (Bugarska). Beograd, Kolarčev narodni univerzitet. Borba 32/1967 (14.1.), 13, 7. Podpis: Marija Koren. Zagrebška izdaja.

Koncert na klavsenu Eriha Houpa. Borba 32/1967 (28.2.), 57, ?. Podpis: Marija Koren. Beograjska izdaja. - Cirilica. - Popisano po: Bibliografija Jugoslavije 1967, 1-2, 17.

Afirmacija mladih. Koncert komornog orkestra Muzičke akademije u Beogradu. Dirigent Dušan Skovran, solisti Vladimir Krpan, klavir, Dejan Mijajev, violina, Božidarka Nikolić, violina i Zorica Jovanović, sopran. Beograd, Kolarčev narodni univerzitet. Borba 32/1967 (11.3.), 68, 8. Podpis: Marija Koren. Zagrebška izdaja.

Majstorstvo Danila Šafrana. Solistički koncert violončelista Danila Šafrana, Moskva; za klavirom Mihail Muntjan, Moskva. Beograd, Kolarčev univerzitet, 3. marta 1967, Borba 32/1967 (14.3.), 71, 8. Podpis: Marija Koren. Zagrebška izdaja. 
Koncert Dušana Trbojevića. Borba 32/1967 (1.4.), 88, ?. Podpis: Marija Koren. Beograjska izdaja. - Cirilica. - Popisano po: Bibliografija Jugoslavije 1967, 3-4, 203.

Profinjeni muzičar Jurica Muraj. Borba 32/1967 (11.4.), 99, 8. Podpis: Marija Koren. Zagrebška izdaja.

Gosti iz Praga i Sofije. Beogradska muzička panorama. Borba 32/1967 (25.4.), 113, 7. Podpis: Marija Koren. Zagrebška izdaja.

Koncert Džeroma Loventala. Borba 32/1967 (6.5.), 122 ?. Podpis: Marija Koren. Beograjska izdaja. - Cirilica. - Popisano po: Bibliografija Jugoslavije 1967, 5-6, 397.

Bahovo veče. Beogradska muzička panorama. Borba 32/1967 (20.5.), 136, 7. Podpis: Marija Koren. Zagrebška izdaja.

Tri uspjele večeri. Borba 32/1967 (27.5.), 143, 7. Podpis: Marija Koren. Zagrebška izdaja.

Koncert Borodin-kvarteta. Borba 32/1967 (30.5.), 146 ?. Podpis: Marija Koren. Beograjska izdaja. - Cirilica. - Popisano po: Bibliografija Jugoslavije 1967, 5-6, 397.

Nerazumljiv i neprihvatljiv izbor. U povodu premijere Kalmanove "Kneginje čardaša u beogradslom Savremenom pozorištu. Borba 32/1967 (6.6.), 153, 9. Podpis: Marija Koren. Zagrebška izdaja.

Jubilej Svetomira Nastasijevića. Borba 32/1967 (13.6.), 160, 9. Podpis: Marija Koren. Zagrebška izdaja.

S ukusom i mjerom. U povodu premijere Verdijevog Trubadura u Beogradskoj operi. Borba 32/1967 (1.7.), 178, 7. Podpis: Marija Koren. Zagrebška izdaja.

Bogato, zanimljivo, privlačno. Koncerti na Dubrovačkim ljetnim igrama. Borba 32/1967

(29.8.), 237, 6. Podpis: Marija Koren. Zagrebška izdaja.

Prvo izvođenje »Difrakcija« Berislava Popovića. Pro musica 1967, 21, 22-23. Podpis: Marija Koren. Cirilica.

Koncert UMUS-a. Pro musica 1967, 21, 23. Podpis: M. K. Cirilica.

Antička veličina i savremena groteska na sceni Beogradske opere. Dve premijere u operi.

Pro musica 1967, 22, 24-25. Podpis: Marija Koren. Cirilica.

Beograd. Pro musica 1967, 24, 20-21. Podpis: Marija Koren. Rubrika: Vesti iz zemlje. - Cirilica.

Kritičari o protekloj sezoni. Tribina. Pro musica 1967, 26, 10-11. Podpis: Marija Koren. Sodelovali: Branko Dragutinović, Marija Koren in Milutin Radenković. - Cirilica. Muzikološki kongres u Ljubljani. Pro musica 1967, 27, 16, 33. Podpis: Marija Koren. Cirilica.

\section{8}

\section{Članki}

Srbske teme v ruski glasbi druge polovice 19. stoletja. Muzikološki zbornik 4/1968, 78-87. Podpis: Marija Koren

Građa za biografiju Vojislava Vučkovića. - V: Vojislav Vučković [2]. Umetnik i borac. Lik, sećanja, svedočanstva. Redaktor Vlastimir Peričić. Beograd, Nolit, 1968. Str. 13-93. Podpis: Građu prikupila Marija Koren.

Vojislav Vučković. Pro musica 1968, 28, 8-9. Podpis: Marija Koren. Cirilica.

Naša mišljenja. [O nekim osobenostima beogradskog koncertnog života koje se ogledaju u ovoj sezoni]. Pro musica 1968, 38, 2-3. Brez podpisa, avtorstvo je razvidno iz podnaslova. Cirilica. 
Srpska opera od Stanislava Biničkog do Stanojla Rajičića. Nin 18/1968 (3.11.), 930, 12-13. Podpis: Marija Koren. Rubrika: Ličnosti i dela. - Cirilica.

\section{Ocene, poročila}

Nova dela u Nišu. Pro musica 1968, 32-33, 15-16. Podpis: Marija Koren. Cirilica.

"Sa poprišta večnog Vizanta i Rima«. Jubilarna sezona 100-godišnjice osnivanja Narodnog pozorišta u Beogradu. Telegram 9/1968 (25.10.), 443, 6. Podpis: Marija Koren.

\section{Spremna besedila}

Slovenska glasbena ustvarjalnost in povojno koncertno življenje Beograda. Koncertni list. Glasilo Slovenske filharmonije 1968-69, 1, 6-8. Podpis: Marija Koren.

\section{9}

\section{Članki}

Treperenja jednog senzibiliteta. Problem nacionalnog u novijoj srpskoj muzici. Odjek 22/1969 (15.3.), 6, 7. Podpis: Marija Koren. Esej nagrađen trećom nagradom na konkursu »Odjeka».

Milan Ristić. Portreti umetnika. Pro musica 1969, 41-42, 4-5, 9. Podpis: Marija Koren.

Nacionalno u delima Ljubice Marić i Milana Ristića. - V: Mokranjčevi dani 1968. Zbornik radova sa sastanaka etnologa, folklorista $i$ muzikologa. Urednik Tomislav Mijović. Negotin, Organizacioni odbor »Mokranjčevi dani«; Zaječar, Novinska ustanova »Timok«, 1969. Str. 14-24. Podpis: Marija Koren. Cirilica.

\section{Ocene, poročila}

Primjer ranog srpskog muzičkog ekspresionizma. Konjovićev »Knez od Zete« na sceni Beogradske opere. Telegram 10/1969 (24.1.), 456, 7. Podpis: Marija Koren.

\section{Spremna besedila}

Živković - Honegger. Koncertni list. Glasilo Slovenske filharmonije 1968-69, 5, 14-15. Podpis: Marija Koren.

\section{0}

\section{Članki}

Mihailo Vukdragović. Povodom sedamdesetog rođendana. Pro musica 1970, 51-52, 12. Podpis: Marija Koren. Cirilica.

Mihailo Vukdragović. Pro musica 1970, posebna edicija "Jugoslovenske horske svečanosti 1970«, 6-7. Podpis: Marija Koren. Cirilica.

Petar Konjović. In memoriam. Naši razgledi 19/1970 (27.11.), 22, 671-672. Podpis: Marija Koren. 


\section{1}

\section{Članki}

Glasbeno šolstvo v Srbiji pred reformo. Naši razgledi 20/1971 (26.2.), 4, 111-112. Podpis: Marija Koren.

Vladimir Marković. Portreti umetnika. Pro musica 1971, 54, 4-5. Podpis: Marija Koren. Cirilica.

Slavenski. Naša istorija i naša savremenost. Povodom 75-godišnjice rođenja 11. V 1896. Pro musica 1971, 55-56, 10-11, 23. Podpis: Marija Koren. Cirilica.

\section{Ocene, poročila}

Da li je BEMUS izraz naših moći. Muzičari i Kongres kulturne akcije: Otvoren BEMUS, završeno međunarodno takmičenje mladih. Zalažemo se za takvu koncepciju BEMUS-a koji će našoj publici prikazati značajna dela savremene svetske muzičke literature i koji će znati da afirmiše našu muzičku umetnost. Politika 68/1971 (9.10.), 20838, Kultura-umetnost, 15/1971, 841, 1 (15). Podpis: Marija Koren. Dopolnilo: 68/1971 (10.10.), 20839, 17. - Cirilica.

Premijera "Sonore«. III beogradske muzičke svečanosti. Novo delo beogradskog kompozitora Vladana Radovanovića. Politika 68/1971 (10.10.), 20839, 17. Podpis: Marija Koren. Vsebuje tudi: Gostovanje Ljubljanske opere. - Cirilica.

Pohvala inicijativi i ostvarenju. Završeno takmičenje mladih muzičara. Politika 68/1971 (11.10.), 20840, 9. Podpis: Marija Koren. Cirilica.

Svežina češke renesanse. BEMUS 71. Koncert Praških madrigalista u atrijumu Narodnog muzeja. Politika 68/1971 (12.10.), 20841, 12. Podpis: Marija Koren. Vsebuje tudi: Duo velikih majstora. Pjer Košero i Rože Delmot u Velikoj dvorani Doma sindikalista. - Cirilica.

Nespojivi stilski elementi. BEMUS 71. Kamerni baletski ansambl iz Njujorka na sceni Narodnog pozorišta. Politika 68/1971 (14.10.), 20843, 12. Podpis: Marija Koren. Vsebuje tudi: Čista kamerna stilizacija. Koncert Anastazije Božikove. - Cirilica.

Kako se neguje svoje muzičko nasleđe. BEMUS 71. Koncert orkestra Francuske radio-televizije u Domu sindikata. Politika 68/1971 (15.10.), 20844, 12. Podpis: M. K. Cirilica.

Majstori pevači. Beogradske muzičke svečanosti 71. Beogradski duvački kvintet: BEMUSov rezervat jugoslovenske muzike. Politika 68/1971 (16.10.), 20845, 20. Podpis: Marija Koren. Vsebuje tudi: Izvorni folklor u galeriji fresaka; Koncert Olge Đokić. - Cirilica.

Fenomen zvani Beogradska filharmonija. BEMUS. U dvorani Kolarčevog narodnog univerziteta izvedena dela Ristića, Bramsa i Čajkovskog. Politika 68/1971 (18.10.), 20847, 9. Podpis: Marija Koren. Naslovi delov članka: Koncert Tokijskog gudačkog kvarteta; Šopenovo veče Haline Černi-Štefanske. - Cirilica.

Jovan Kolunđija i gosti iz Moskve. BEMUS. Koncert Državnog simfonijskog orkestra SSSR u dvorani Kolarčevog narodnog univerziteta. Politika 68/1971 (19.10.), 20848, 12. Podpis: Marija Koren. Vsebuje tudi: Vrhunska interpretacija Lida. Koncert Eve Novšak-Houška u dvorani Beogradske filharmonije. - Cirilica.

Manje - znači više. BEMUS 71. Koncert Moskovskog kamernog ansambla u dvorani Kolarčevog narodnog univerziteta. Politika 68/1971 (20.10.), 20849, 12. Podpis: Marija Koren. Vsebuje tudi: Renesansa ponovno aktuelna. Bečki ansambl »Musica antiqua» u atrijumu Narodnog muzeja. - Cirilica. 
»Pasija po Jovanu« prvi put u Beogradu. BEMUS 71. Koncert Hora i orkestra RTV Beograd; dirigent Borivoje Simić. Politika 68/1971 (21.10.), 20850, 12. Podpis: Marija Koren. Cirilica.

Andre Navara sa Beogradskom filharmonijom. BEMUS 71. Koncert na Kolarčevom narodnom univerzitetu. Politika 68/1971 (22.10.), 20851, 12. Podpis: M. K. Cirilica.

\section{2}

\section{Članki}

Kriza epohe kao drama umjetnika. (Gustav Maler). Ovdje 4/1972, 36, 20. Podpis: Marija Koren. Cirilica.

U susret ekspresionističkoj muzičkoj drami. (Rihard Štraus). Ovdje 4/1972, 43, 25. Podpis: Marija Koren. Cirilica.

\section{Ocene, poročila}

Razvojne niti glasbene zgodovine. Vilko Ukmar: Glasba v preteklosti, Državna založba Slovenije 1972. Naši razgledi 21/1972 (22.12.), 24, 671. Podpis: Marija Koren.

\section{3}

\section{Monografske publikacije}

Elementi ekspresionističke orijentacije u srpskoj muzici do 1945. godine. Inauguralna disertacija. [Beograd, M. Koren], 1973. 355 f. Podpis: Marija Koren. Povzetek v slovenščini in angleščini: Muzikološki zbornik 10/1974, 103-106.

\section{Članki}

Klod Debisi - oslobađanje zvuka. Ovdje 5/1973, 45, 25. Podpis: Marija Koren. Cirilica.

\section{Ocene, poročila}

Beogradska opera u sezoni 1972/73. Pro musica 1973, 64, 12. Brez podpisa. Avtorstvo na podlagi opombe o odhodu iz redakcije, str. 13. - Cirilica.

Muzička omladina u novoj sezoni. Pro musica 1973, 64, 13. Brez podpisa. Avtorstvo na podlagi opombe o odhodu iz redakcije, str. 13. - Cirilica.

\section{4}

\section{Članki}

Ekspresionistični elementi v skladbah Vojislava Vučkovića. Muzikološki zbornik 10/1974, 48-66. Podpis: Marija Koren

\section{7}

\section{Monografske publikacije}

Delo kompozitora. Stvaralački put Milana Ristića od prve do šeste simfonije. Beograd, Univerzitet umetnosti, 1977. 256 str. 


\section{8}

\section{Spremna besedila}

Alfred Schnittke: Concerto grosso per due violini, clavicembalo (anche pianoforte) e orchestra d'archi (1976/77). Wien - London, Universal Edition, cop. 1978. [XIV], 80 str. (Philharmonia Partituren, 488). Marija Bergamo: Vorwort, str. [I-IV]. V nemščini, angleščini in francoščini. Podpis: Dr. M. Bergamo.

\section{9}

\section{Spremna besedila}

Alfred Schnittke: Konzert No. 3 für Violine und Kammerorchester (1978). Wien - London, Universal Edition, cop. 1979. [X], 38 str. (Philharmonia Partituren, 496). Marija Bergamo: Vorwort, str. I-II. V nemščini, angleščini in francoščini. Brez podpisa. Formübersicht, VII-IX. Podpis: Dr. M. Bergamo.

\section{0}

\section{Monografske publikacije}

Elementi ekspresionističke orijentacije u srpskoj muzici do 1945. godine. Beograd, Srpska akademija nauka i umetnosti, 1980. 292 str. (Posebna izdanja, DXXVI. Odeljenje likovne i muzičke umetnosti, 3). Cirilica.

\section{Članki}

Osamdeset Vukdragovićevih godina. Zvuk 1980, 4, 80-85. Podpis: Marija Koren-Bergamo.

\section{1}

\section{Spremna besedila}

Alfred Schnittke: 2. [Zweites] Streichquartett (1981). Wien - London, Universal Edition, cop. 1981. [VIII], 31 str. (Philharmonia Partituren, 501). Marija Bergamo: Vorwort, str. [I-III]. V nemščini, angleščini in francoščini. Podpis: M. B.

\section{2}

\section{Članki}

„Čaščen, a nezažalen ..." Ernst Krenek danes - v luči dveh novejših orgelskih skladb. Muzikološki zbornik 18/1982, 83-93.

"Cortesova vrnitev« Pavla Šivica. - V: Slovenska opera v evropskem okviru. Ob njeni 200 letnici. Simpozij 20.-21. oktobra 1982. Uredila Dragotin Cvetko in Danilo Pokorn. Ljubljana, Slovenska akademija znanosti in umetnosti, 1982. Str. 153-158. Prispevek na simpoziju. 


\section{3}

\section{Monografske publikacije}

Srpske teme u delima ruskih i sovjetskih kompozitora. Beograd, Univerzitet umetnosti, 1983. 42 str. (Magistarski radovi, 2). Podpis: Marija Koren - Bergamo.

\section{Članki}

Ljubica Marić. Glasbena mladina 13/1983 (18.2.), 5, 12.

Dileme i prelomi jugoslovenskih muzičkih tridesetih godina. Zvuk 1983, 4, 5-7. Referat na kolokviju v Radencih.

\section{Mentorstvo}

Vladimir Boljunčić: Ivan Matetić Ronjgov in glavne značilnosti njegovega dela. Diplomska naloga. Mentorica: Marija Bergamo. Ljubljana, [V. Boljunčić], 1983. 94 f. Filozofska fakulteta v Ljubljani, Oddelek za muzikologijo.

\section{4}

\section{Spremna besedila}

Alfred Schnittke: 3. [Drittes] Streichquartett (1983). Wien - London, Universal Edition, cop. 1984. [VI], 30 str. (Philharmonia Partituren, 522). Marija Bergamo: Vorwort, str. [I-II]. V nemščini, angleščini in francoščini.

Alfred Schnittke: Konzert No. 4 für Violine und Orchester (1984). Wien - London, Universal Edition, cop. 1984. [XII], 79 str. (Philharmonia Partituren, 525). Marija Bergamo: Vorwort, str. [III-V]. V nemščini, angleščini in francoščini.

\section{Mentorstvo}

Ada Klinkon: Stilna podoba glasbe Sergeja Prokofjeva od prve do sedme simfonije. Diplomska naloga. Mentorica: Marija Bergamo. Ljubljana, [A. Klinkon], 1984. 54 f. Filozofska fakulteta v Ljubljani, Oddelek za muzikologijo.

Katarina Virant: Razmišljanja o nekaterih vidikih estetskega na področju otroške glasbe in glasbe za otroke. Diplomska naloga. Mentorica: Marija Bergamo. Ljubljana, [K. Virant], 1984. 77 f. Filozofska fakulteta v Ljubljani, Oddelek za muzikologijo.

\section{Prevodi}

Borut Loparnik: Razgovor sa stvaraocem. Biti kompozitor. Prevedla Marija Bergamo. Zvuk 1984, 1, 28-34.

\section{5}

\section{Monografske publikacije}

Humor kao sredstvo realističkog muzičkog jezika. U muzici XIX veka. Beograd, Univerzitet umetnosti, 1985. 104 str. (Magistarski radovi, 3). Podpis: Marija Koren-Bergamo. 


\section{Članki}

Podoba in pomen glasbeno avantgardnega (na primeru srbske glasbe na začetku 20. stoletja). Sodobnost 33/1985, 2, 213-217. Referat na simpoziju Slovenska zgodovinska avantgarda 1910-1930.

Musik im südslawischen Raum in der zweiten Hälfte des 16. Jahrhunderts. - V: Jacobus Gallus and his time. [Jacobus Gallus] in njegov čas. Simposium / Simpozij: 23.-25. oktober 1985. Editors / Uredila Dragotin Cvetko, Danilo Pokorn. Ljubljana, Slovenska akademija znanosti in umetnosti, 1985. Str. 26-33.

Zaštićenost tradicijom. Uz 85-ti rođendan Mihaila Vukdragovića. Zvuk 1985, 3-4, 66-69.

\section{Ocene, poročila}

Jedna neobična knjiga. Borut Loparnik: Biti skladatelj (Razgovori s Primožem Ramovšem) Slovenska Matica, Ljubljana, 1984, 227 str. Zvuk 1985, 2, 96-97.

\section{Spremna besedila}

Alfred Schnittke: Trio für Violine, Bratsche und Violoncello (1985). Im Auftrag der Alban Berg Stiftung zum 100. Geburtsjahr Alban Berg's geschrieben. Wien - London, Universal Edition, cop. 1985. [IV], 24 str. (Philharmonia Partituren, 528). Marija Bergamo: Vorwort, str. [II]. V nemščini, angleščini in francoščini.

\section{Mentorstvo}

Jasna Blažič: Stilni razvoj Franka Martina. Diplomska naloga. Mentorica: Marija Bergamo. [S. 1., J. Blažič], 1985. 80 f. Filozofska fakulteta v Ljubljani, Oddelek za muzikologijo. Ksenija Selan: Nekateri splošni in posebni vidiki muzikoterapije kot znanosti in praktičnega terapevtskega postopka. Diplomska naloga. Mentorica: Marija Bergamo. Ljubljana, [K. Selan], 1985. 195 f. Filozofska fakulteta v Ljubljani, Oddelek za muzikologijo.

\section{6}

\section{Članki}

O nekim stilno-jezičkim značajkama opere »Ekvinocij« Ivana Brkanovića. Muzička kultura 4/1986, 4-5, 5-8. Popisano po: Bibliografija Jugoslavije 1986, 12, 712.

\section{Mentorstvo}

Tatjana Gregorič: Glasbeno delo Emila Komela. Diplomska naloga. Mentorica: Marija Bergamo.

[S. 1., T. Gregorič], 1986. 112 f. Filozofska fakulteta v Ljubljani, Oddelek za muzikologijo.

\section{7}

\section{Članki}

Mediteranski vidiki jugoslovanskega glasbenega prostora. Muzikološki zbornik 23/1987, 5-17. Prispevek s posvetovanja-kokvija o »mediteranski glasbi«, ki ga je grški nacionalni komite organiziral v okviru festivala »Mediteranska glasba«, Atene, 7.-14.11.1985 v Evropskem letu glasbe. 
Glasbena ustvarjalnost med spoštovanjem tradicije in »odkrivanjem novega«. - V: Vprašanja in opredelitve ustvarjalnosti ter njene vloge v razvoju glasbene kulture. Slovenski glasbeni dnevi, Ljubljana - Bled, 3.-5. april 1986. Uredil Primož Kuret. Ljubljana, Festival, 1987. Str. 23-28.

Tschechisch-jugoslawische musikalische Interaktion zur Zeit der historischen Avantgarden. - V: Soobstoj avantgard. Mednarodni kolokvij. Volume II. Ljubljana, Društvo za estetiko, 1987. Str. 5-15.

[»Razkroj slovenske glasbene zavesti?« Prispevek za okroglo mizo.] - V: Prispevki za okroglo mizo na temo »Razkroj slovenske glasbene zavesti? Ljubljana, Oddelek za muzikologijo Filozofske fakultete, 1987. Str. 12-13. Podpis: Marija Koren-Bergamo.

\section{Mentorstvo}

Nataša Kričevcov: Klasično in romantično kot principa oblikovanja kompozicijskega stavka v Bartokovem »koncertu za orkester«. Diplomska naloga. Mentorica: Marija Bergamo. Ljubljana, [N. Kričevcov], 1987. 31 f. Filozofska fakulteta v Ljubljani, Oddelek za muzikologijo.

\section{8}

\section{Članki}

Značilnosti glasbenega gradiva, sintakse in strukturnega reda simfonije v C-duru Františka Benedikta Dusíka kot kriterij slogovne opredelitve in vrednostne sodbe. Muzikološki zbornik 24/1988, 39-46. Prispevek z mednarodnega simpozija »Evropski glasbeni klasicizem in njegov odmev na Slovenskem", Ljubljana, oktober 1988. - Povzetek v: Evropski glasbeni klasicizem in njegov odmev na Slovenskem. Mednarodni simpozij, Ljubljana, 26.-28.10.1988. [Zbornik razprav]. Uredila Dragotin Cvetko [in] Danilo Pokorn. Ljubljana, Slovenska akademija znanosti in umetnosti, 1988. Str. 91-92.

\section{Ocene, poročila}

»Neredovitost « kao »zakonomjernost«. Važan prilog revalorizaciji znanstvenog rada Pavla Markovca. RAD JAZU br. 409, 5. knjiga Razreda za glazbenu umjetnost i muzikologiju, Zagreb 1988. Urednici: Natko Devčić, Koraljka Kos, Lovro Županović. Arti musices 19/1988, 1, 103-108.

\section{Mentorstvo}

Edvard Bobanović: Glasbeno življenje Pulja od leta 1900 do 1918 kot del družbene in kulturne podobe mesta v istem času. Diplomska naloga. Mentorica: Marija Bergamo. [S. 1., E. Bobanović], 1988. 85 f. Filozofska fakulteta v Ljubljani, Oddelek za muzikologijo.

\section{9}

\section{Monografske publikacije}

Jiří Fukač: Pojmoslovje glasbene komunikacije. Prevedel Andrej Rozman. Slovensko izdajo priredila Marija Bergamo in Andrej Rijavec. Ljubljana, Filozofska fakulteta, Oddelek za muzikologijo, 1989. 94 str. Marija Bergamo: Slovenski izdaji na pot, str. 5-7. 


\section{Članki}

Od »donečega« pojava do transcendentalne »idealne istine«. Po sledi »glasov«, »melodije» in "simfonije» v estetskem sistemu Franceta Vebra. Muzikološki zbornik 25/1989, $15-27$.

Neke stilske osobenosti »Kneza od Zete«Petra Konjovića. - V: Život i delo Petra Konjovića. Zbornik radova sa naučnog skupa održanog od 25. do 27. oktobra 1983, povodom 100-godišnjice kompozitorovog rođenja. Urednik Dimitrije Stefanović. Beograd, Srpska akademija nauka i umetnosti, 1989. (Naučni skupovi, XLIII, Odeljenje likovne i muzičke umetnosti, 2). Str. 65-71.

Fragment o muzički nacionalnom. - V: Folklor i njegova umetnička transpozicija. Radovi sa naučnog skupa održanog od 24.-26. oktobra 1989. godine. Urednik: Vlastimir Peričić. Beograd, Fakultet muzičke umetnosti, 1989. Str. 211-220. Popisano po podatkih v srbski vzajemni bibliografski bazi podatkov COBIB.SR, po RILM Abstracts of Music literature (dostopno prek: Mrežnik - kažipot po informacijskih virih, http://www. nuk.uni-lj.si/nuk/mreznik.asp) ter po podatkih iz največjega svetovnega vzajemnega kataloga WorldCAT (http://worldcat.org/).

Versuch zum musikalisch Nationalen. International review of the aesthetics and sociology of music 20/1989, 2, 169-181. Ponatis: Folklore and its artistic transposition. Proceedings of the scientific assembly (Belgrade, 24.-26. X 1989). Editors: D. Dević, V. Peričić, M. Veselinović. Belgrade, Faculty of music arts, 1990. Str. 101-115.

Glazba rubnih područja. Prilog pitanju samobitnosti tzv. "malih« glazbenih kultura. - V: Radovi Zavoda za znanstveni rad Varaždin. Knjiga 3. Urednik Andre Mohorovičić. Varaždin, Jugoslavenska akademija znanosti i umjetnosti, 1989. Str. 207-218.

Johann Michael: drugi in drugačni Haydn (1737-1806). - V: Mozart - kdo je to? Spremna publikacija k ciklusu koncertov o Mozartu komornega ansambla Slovenicum. Izdal Uroš Lajovic. Ljubljana, Festival Ljubljana, 1989. Str. 48-52.

\section{Mentorstvo}

Veronika Brvar: Renesančna plesna glasba 16. stoletja s poudarkom na plesni dvojici pavane in galiarde. Diplomska naloga. Mentorica: Marija Bergamo. Ljubljana, [V. Brvar], 1989. 80 f. Filozofska fakulteta v Ljubljani, Oddelek za muzikologijo.

\section{Prevodi}

Borut Loparnik: Naturae visus. Sa slovenskog prevela Marija Bergamo. Zvuk 1989, 1, 13-17.

Lojze Lebič: Quartetto Stanka Horvata. Sa slovenskog prevela Marija Bergamo. Zvuk 1989, 1, 37-52.

Majda Eržen: Počeci klavirskog tria u Sloveniji. Sa slovenskog prevela Marija Bergamo. Zvuk 1989, 2, 49-54.

Darja Frelih: Josip Ipavec. Avtorska plošča. Založba kaset in plošč RTV Ljubljana. Sa slovenskog prevela Marija Bergamo. Zvuk 1989, 3, 91.

Pavle Merkù: Riječ i zemlja u stvaralačkoj poetici L. Lebiča. Sa slovenskog prevela M. Bergamo. Zvuk 1989, 4, 53-57. 


\section{0}

\section{Članki}

»Življenja zmožni«. Zgodnji samospevi Lucijana Marije Škerjanca. - V: Glasba in poezija. Koncerti, strokovno posvetovanje. Slovenski glasbeni dnevi, Ljubljana, Celje, Slovenj Gradec, Maribor, od 30. marca do 6. aprila 1990. Uredila Primož Kuret, Julijan Strajnar. Ljubljana, Festival, 1990. Str. 193-201.

\section{Ocene, poročila}

Jiří Fukač: Pojmoslovje glasbene komunikacije; rasprava, 100 stranica, sa slovačkog na slovenski preveo A. Rozman; Izdanje Filozofskog fakulteta u Ljubljani, 1989. Oko 1(18)/1990 (8.3.), 5(469), 39. Podpis: M. Bergamo.

\section{Mentorstvo}

Matjaž Barbo: Slovenska glasbena zavest v preteklosti in sedanjosti. Izbrana poglavja. Diplomska naloga. Mentorica: Marija Bergamo. Ljubljana, [M. Barbo], 1990. 156 f. Filozofska fakulteta v Ljubljani, Oddelek za muzikologijo.

Ksenija Mahne: »Zgodba« o »zgodbi«. Igor Stravinski: »Zgodba o vojaku«. Analitična razčlenitev. Diplomska naloga. Mentorica: Marija Bergamo. Ljubljana, [K. Mahne], 1990. 120 f. Filozofska fakulteta v Ljubljani, Oddelek za muzikologijo.

Karmen Salmič Kovačič: Vpliv estetske misli Franceta Vebra na »Uvod v glasbo« Stanka Vurnika. Diplomska naloga. Mentorica: Marija Bergamo. Ljubljana, [K. Salmič, 1990]. 43 f. Filozofska fakulteta v Ljubljani, Oddelek za muzikologijo.

Mojca Tomažič: Pomen in vloga MPF v glasbenem življenju Celja. Diplomska naloga. Mentorica: Marija Bergamo. Celje, [M. Tomažič], 1990. 45 f. Filozofska fakulteta v Ljubljani, Oddelek za muzikologijo.

\section{1}

\section{Članki}

Nacionalno i kozmopolitsko u muzičkoj poetici Stevana Hristića. - V: Život i delo Stevana Hristića. Zbornik radova sa naučnog skupa održanog 19. i 20. novembra 1985, povodom 100-godišnjice kompozitorovog rođenja. Urednik Dimitrije Stefanović. Beograd, Srpska akademija nauka i umetnosti, Muzikološki institut, 1991. (Naučni skupovi, LV. Odeljenje likovne i muzičke umetnosti, 3). Str. 9-14. Deloma v cirilici.

\section{Ocene, poročila}

Leuven - History of European ideas: „European nationalism: toward 1992«, 3.-8.9.1990. 2. konferencija Internacionalnog društva za studij europskih ideja (ISSEI). Arti musices 22/1991, 1, 97-100. Poročilo z znanstvenega skupa.

Brno - Bohuslav Martinů, njegovi učenci, prijatelji i suvremenici, 1.-3.10.1990. Arti musices 22/1991, 1, 101-104. Poročilo z znanstvenega skupa. 


\section{Mentorstvo}

Ingrid Gortan: Igor stravinski: Divertimento. Analiza skladbe in oris skladateljevega neoklasicističnega principa. Diplomska naloga. Mentorica: Marija Bergamo. Ljubljana, [I. Gortan], 1991. 74 f. Filozofska fakulteta v Ljubljani, Oddelek za muzikologijo.

\section{2}

\section{Članki}

Koncertantnost kot gibalo strukture Škerjančevih klavirskih koncertov. - V: Slovenska glasba $v$ preteklosti in sedanjosti. Zbornik predavanj. Slovenski glasbeni dnevi, Ljubljana, Kostanjevica, 12.-16. aprila 1988. Uredil Primož Kuret. Ljubljana, Kres, 1992. Str. 244-252.

Tartinijevo umevanje glasbe med »logiko« in estetiko. Muzikološki zbornik 28/1992, 11-14. Prispevek z mednarodnega muzikološkega simpozija Tartini '92, Piran, 11.-12.9.1992.

\section{Ocene, poročila}

Glazba u »živopisnoj ljudskoj košnici na granici Balkana i mediterana«. Mirjana Škunca: Glazbeni život Splita od 1860. do 1918, Književni krug Split 1991, Znanstvena djela br. 37, 540 str. Arti musices 23/1992, 1, 63-66. Ponatis: Mogućnosti 40/1993, 3-4, 192-194.

Teorijska misao pred novim oblicima svijesti i novim shvaćanjima umjetnosti. Helga de la Motte-Haber: Musik und Bildende Kunst: von der Tonmalerei zur Klangskulptur, Laaber-Verlag, Laaber 1990. Arti musices 23/1992, 2, 193-197. Recenzija.

\section{3}

\section{Članki}

Wandel des Begriffs »Avantgarde« in musiktheoretischen und -ästhetischen Denken in Jugoslawien zwischen 30-ger Jahren und heute. - V: Colloquium. An der Epochen-und Stilwende. Brno 1985. Music in metamorphoses of aesthetic categories. Brno 1986. Chairman Jiř́i Vysloužil, ed. Petr Macek. Brno, Masarykova univerzita - filozofická fakulta, 1993. Str. 258-264.

Neoklassizistische Tendenzen in der Musik des jugoslawischen Raums zwischen zwei Weltkriegen. - V: Colloquium. Bohuslav Martinü, his pupils, friends and contemporaries. Brno 1990. Chairman Jiř́i Vysloužil, ed. Petr Macek. Brno, Ústav hudebni vědy filozofické fakulty MU, 1993. Str. 112-115.

Glasbeno-avtonomno in glasbeno-funkcionalno na primeru Bravničarjeve opere »Hlapec Jernej in njegova pravica". - V: Opera kot socialni ali politični angažma. Koncerti, strokovno posvetovanje. Slovenski glasbeni dnevi, Ljubljana, od 5. maja do 8. maja 1992. Uredil Primož Kuret. Ljubljana, Festival, 1993. Str. 36-45.

Some ideas about the national in music. History of European ideas 16/1993, 4-6, 683-689. Special issue: Second international conference of the International society for the study of European ideas. European nationalism: toward 1992, part IV. 
Uvod v vprašanja glasbene kritike. Bilten SMD 1993, 1, 5-7.

Težave z glasbo. Misli na rob glasbenemu danes in tukaj. Nova revija 12/1993, 136-137, Ampak, LVIII-LXII.

Petdeset godina poslije ... Gotovčeva opera »Ero sa onoga svijeta« i hrvatska glazbena tradicija. Mogućnosti 40/1993, 8-10, 136-143.

Blaukopfov pledoaje za "razumevajočo« sociologijo glasbe. Spremna beseda. - V: Kurt Blaukopf: Glasba v družbenih spremembah. Temeljne poteze sociologije glasbe. Prevedel Štefan Vevar. Strokovni pregled in spremna beseda Marija Bergamo. Ljubljana, ŠKUC, Filozofska fakulteta, 1993. (Studia humanitatis). Str. 367-377.

\section{Ocene, poročila}

Brno - Internacionalni muzikološki kolokvij »Etnonacionalni međuodnosi u srednjoeuropskoj glazbi«, 5.-7.10.1992. Arti musices 24/1993, 1, 119-121. Poročilo z znanstvenega skupa.

\section{Mentorstvo}

Lada Duraković: Natko Devčić: »Labinska vještica«. Diplomska naloga. Mentorica: Marija Bergamo. Ljubljana, [L. Duraković], 1993. 81 f. Filozofska fakulteta v Ljubljani, Oddelek za muzikologijo.

Janja Galičič: Nekatere značilnosti kompozicijskega stavka Bele Bartoka. V luči zgledov iz zbirke klavirskih skladb »Mikrokosmos«. Diplomska naloga. Mentorica: Marija Bergamo. Ljubljana, [J. Galičič], 1993. 86 f., [69] f. Filozofska fakulteta v Ljubljani, Oddelek za muzikologijo.

\section{4}

\section{Monografske publikacije}

Spisi, polemike, manifesti. Izbrala, uredila in napisala spremno besedo Marija Bergamo. Prevod iz nemščine Marija Bergamo, prevod iz italijanščine Pina Kalc. Ljubljana, Slovensko muzikološko društvo, Oddelek za muzikologijo Filozofske fakultete, 1994. (Varia musicologica, 1).

\section{Članki}

Je glasbeni realizem "zgodovinska nujnost«? - V: Individualni in generacijski ustvarjalni ritmi v slovenskem jeziku, književnosti in kulturi. Ob 10-letnici smrti Marje Boršnikove. Mednarodni simpozij v Ljubljani od 24. do 26. junija 1992 pod vodstvom Toneta Pretnarja. Uredila Marko Juvan in Tomaž Sajovic. Ljubljana, Filozofska fakulteta, 1994. (Obdobja, 14). Str. 257-262.

Ali zmore glasba odgovoriti takim zahtevam? Vsaka revolucija je grandiozna simfonija. (Lunačarski, 1926). Borec 1994, 526-528, 22-30. Prispevek s kolokvija o estetiki in nasilju.

Glasba v prelomnem času: »Napredek s pomočjo tradicije« in restavracija. - V: Spisi, polemike, manifesti. Izbrala, uredila in napisala spremno besedo Marija Bergamo. Prevod iz nemščine Marija Bergamo, prevod iz italijanščine Pina Kalc. Ljubljana, Slovensko muzikološko društvo, Oddelek za muzikologijo Filozofske fakultete, 1994. (Varia musicologica, 1). Str. 123-136. 


\section{Mentorstvo}

Ivana-Paula Gortan: Glasbeno šolstvo v Pulju v času avstro-ogrske vladavine (1906-1918). Diplomska naloga. Mentorica: Marija Bergamo. Ljubljana, [I.-P. Gortan], 1994. 81 f. Filozofska fakulteta v Ljubljani, Oddelek za muzikologijo.

\section{5}

\section{Članki}

Über einige Aspekte der Interkulturalität aus der Sicht der Musik. - V: Kulturelle wechselseitigkeit in Mitteleuropa. Deutsch und slowenische Klutur im slowenischen Raum vom Anfang des 19. Jahrhunderts bis zum Zweiten Weltkrieg (Symposium, Ljubljana 29. -31. Oktober 1990). Herausgegeben von Feliks J. Bister und Peter Vodopivec. Ljubljana, Oddelek za zgodovino Filozofske fakultete, 1995. (Wissenschaftliche Bibliothek Österreich-Slowenien, 1). Str. 51-58.

Zwischen Serenade und Symphonie. František Josef Benedikt Dusík (1765 - nach 1817). - V: Off-Mozart. Glazbena kultura i mali majstori" srednje Europe 1750.-1820. Radovi s međunarodnog muzikološkog skupa održanog u Zagrebu, Hrvatska, 1.-3.10.1992. Uredila Vjera Katalinić. Zagreb, Hrvatsko muzikološko društvo [etc.], 1995. (Serija Muzikološki zbornici, br. 3). Str. 55-66.

Od Fantasiermaschine do računalnika - o mejah formalizacije skladateljskega dela. - V: Glasba v tehničnem svetu - musica ex machina. Koncerti, simpozij. Slovenski glasbeni dnevi, Ljubljana, Novo mesto, Ptuj, od 11. do 15. aprila 1994. Uredil Primož Kuret. Ljubljana, Festival, 1995. Str. 25-30.

Osterčeva "avantgardnost «v luči drugega godalnega kvarteta (1934). Muzikološki zbornik 31/1995, 63-69. Prispevek z muzikološkega kolokvija ob 100-letnici rojstva Slavka Osterca, Ljubljana, 12.10.1995.

Europäische Musik - Fakt und Fiktion zugleich. History of European ideas 20/1995, 1-3, 447-452. Special issue: Third international conference of the International society for the study of European ideas. European integration and the European mind: cultural hegemony or dialoge of culture, part III.

\section{Spremna besedila}

[Spremna beseda]. - V: Alfred Schnittke: Klavierquintett [E] Streichtrio. Nadia Magomedbekowa, [piano], Kvartet im. M. Lysenka. Bietigheim, Amati, 1995. 1 CD, stereo. Program notes by Marija Bergamo. Popisano po: podatkih iz največjega svetovnega vzajemnega kataloga WorldCAT (http://worldcat.org/).

\section{Mentorstvo}

Marjeta Jan: Položaj in delovanje ljubljanskih glasbeno-poustvarjalnih ustanov med leti 1982 in 1994. Diplomska naloga. Mentorica: Marija Bergamo. [Ljubljana, M. Jan], 1995. 56 f., [39] f. Filozofska fakulteta v Ljubljani, Oddelek za muzikologijo.

Leon Stefanija: Analitična metoda Allena Fortea in njen domet ob analizi Noneta Slavka Osterca. Diplomska naloga. Mentorica: Marija Bergamo. Ljubljana, [L. Stefanija], 1995. 2 zv. (58, 61 str.). Filozofska fakulteta v Ljubljani, Oddelek za muzikologijo. 
Suzana Vidas: Individualizacija klasicistične polifonije v kompozicijskem stavku Frederica Chopina. Diplomska naloga. Mentorica: Marija Bergamo. Ljubljana, [S. Vidas], 1994, [i.e. 1995]. 36 f. Filozofska fakulteta v Ljubljani, Oddelek za muzikologijo.

\section{6}

\section{Članki}

Razmerje med govorno in glasbeno intonacijo - na sledi korelacije, ki utemeljuje identiteto.

- V: Kopitarjev zbornik. Mednarodni simpozij v Ljubljani, 29. junij do 1. julij 1994 Jernej Kopitar in njegova doba, simpozij ob stopetdesetletnici njegove smrti. Uredil Jože Toporišič. Ljubljana, Filozofska fakulteta, Oddelek za slovanske jezike in književnosti, Seminar slovenskega jezika, literature in kulture, 1996. (Obdobja, 15). Str. 601-606.

Narava glasbeno-estetske izkušnje. - V: Glasbeni forum. Uredila Milka Ajtnik. Ljubljana, Zavod Republike Slovenije za šolstvo, 1996. Str. 31-33.

Iz rusko-slovenskih glasbenih odnosov: Aleksander Skrjabin-Lucijan Marija Škerjanc. Povzetek. - V: XXXII. seminar slovenskega jezika, literature in kulture. 24.6. -13. 7.1996. Zbornikpredavanj. Uredila Aleksandra Derganc. Ljubljana, Filozofska fakulteta, 1996. Str. 191-193.

Muzikologijski brevijar. Vijenac 64/1996 (13.6.), 4, 28.

Alois Hába im slowenischen musikalischen Raum. - V: Gedanken zu Alois Hába. Herausgegeben von Horst-Peter Hesse und Wolfgang Thies. Anif - Salzburg, Müller-Speiser, 1996. (Wort und Musik, 35). Str. 88-94.

Između iskustvenosti i transcendentalnosti: Matačić i Bruckner. - V: Matačić. Priredila Eva Sedak. Zagreb, Fond Lovro \& Lilly Matačić, AGM, 1996. Str. 209-216.

\section{Prispevki $v$ enciklopedijah in leksikonih}

Rusko-slovenski odnosi. Kulturni odnosi. Glasba. - V: Enciklopedija Slovenije. 10, Pt-Savn. [Urednica zvezka Alenka Dermastia]. Ljubljana, Mladinska knjiga, 1996. Str. 351-354. Podpis: M. Bmo; sopodpisana: S. M. Š. (Simona Moličnik Šivic).

\section{Ocene, poročila}

Ethno-national interrelationships in Central-European Music. Brno, Czech republic, October 5-7, 1992. International review of the aesthetics and sociology of music 27/1996, 2, 208-209.

Varia musicologica 1: F. Busoni, H. Pfitzner. Bilten SMD 1996, 7, 24-25. Predstavitev knjige: Spisi, polemike, manifesti. Izbrala, uredila in napisala spremno besedo Marija Bergamo. Prevod iz nemščine Marija Bergamo, prevod iz italijanščine Pina Kalc. Ljubljana, Slovensko muzikološko društvo, Oddelek za muzikologijo Filozofske fakultete, 1994. (Varia musicologica, 1).

Muzikološki znanstveni skup, Zagreb, 13. i 14. prosinca 1996. Cantus 1996, 89, 13-14.

\section{7}

\section{Monografske publikacije}

Igor Stravinski: Glasbena poetika. Prevedla Marija Bergamo. Ljubljana, Nova revija, 1997. (Zbirka Paradigme). 


\section{Članki}

Uz dvije važne obljetnice. U pohvalu glazbenog reda dviju osporavanih skladateljskih poetika. Šulek - Papandopulo: sučeljavanja u sukladnom. Vijenac 65/1997 (30.1.), 80/V, 25.

Između simfonizma i programnosti. Orkestralna djela Krste Odaka. - V: Krsto Odak. Život $i$ djelo. Radovi s međunarodnog muzikološkog skupa održanog u Zagrebu, Hrvatska, 20-22. listopada 1988. Uredila Eva Sedak. Zagreb, Hrvatsko muzikološko društvo, Hrvatski glazbeni zavod, Odsjek za povijest hrvatske glazbe HAZU, 1997. (Muzikološki zbornici, 4). Str. 53-61.

Med oporo in zavoro: polarnost baročne normativnosti. - V: Glasbeni barok na Slovenskem in evropska glasba. Zbornik referatov z mednarodnega simpozija 13. in 14. oktobra 1994 v Ljubljani. Uredil Ivan Klemenčič. Ljubljana, Znanstvenoraziskovalni center SAZU, Založba ZRC, 1997. Str. 19-25.

Skrjabin - Kandinsky: barva in zvok v funkciji „vibracij človekove duše». - V: Glasba in likovna umetnost. Koncerti, simpozij. Slovenski glasbeni dnevi, Ljubljana, Piran, 23-26. april 1996. Uredil Primož Kuret. Ljubljana, Festival, 1997. Str. 107-118.

Glazbeno kazalište u znaku propusnosti granica sustava. - V: 19. muzički biennale Zagreb, Medunarodni festival suvremene glazbe, 4. travnja 1997. - 12. travnja 1997. Urednik kataloga Sanda Vojković. Zagreb, Hrvatsko društvo skladatelja, Muzički biennale Zagreb, 1997. Str. [3-4].

Krekov »pegaz na uzdi«. Bilten SMD 1997, posebna št., 27-33. Naslov številke: Muzikološki kolokvij ob 75-letnici skladatelja in akademika prof. Uroša Kreka, Zbornik referatov.

Sumnja u formule. Što je za glazbu danas važno? Vijenac 65/1997 (13.11.), 100, 34.

»Racionalizem magičnega nadiha«. Glasbena poetika Igorja Stravinskega v luči njegovega ustvarjalnega opusa. - V: Igor Stravinski: Glasbena poetika. Prevedla Marija Bergamo. Ljubljana, Nova revija, 1997. (Zbirka Paradigme). Str. 139-157.

\section{Ocene, poročila}

Hrvatska glazba između moderne i avantgarde. Muzikološko znanstveno srečanje Hrvatskega muzikološkega društva in Zavoda za sistematsko muzikologijo Glasbene akademije Univerze v Zagrebu. Bilten SMD 1997, 8, 40-42.

Možda ipak treba prihvatiti da Satie-izam postoji? Cantus 1997, 91, 13-15.

Tradicijski glazbeni slojevi kao uporišna točka. Melodram Ericha Urbannera. Cantus 1997, 91, 16.

\section{Mentorstvo}

Rajko Muršič: Dinamika medkulturnega stika. Odnos med rokovsko podkulturo in lokalno kulturo na Tratah v Slovenskih Goricah. Doktorska disertacija. Mentorica: Marija Bergamo; somentor: Božidar Jezernik. Ljubljana, [R. Muršič], 1997. VII, 330 f. Filozofska fakulteta v Ljubljani, Oddelek za etnologijo in kulturno antropologijo.

Leon Stefanija: Glasbeno-analitični nastavki. Med idejo in strukturo. Magistrska naloga. Mentorica: Marija Bergamo; somentor: Andrej Rijavec. Ljubljana, [L. Stefanija], 1997. 126 str. Filozofska fakulteta v Ljubljani, Oddelek za muzikologijo. 


\section{8}

\section{Članki}

Geographische Begriffe als strukturelle Bestimmungen. Übertragungsmöglichkeiten und Begrenzungen. - V: Zagreb 1094-1994. Zagreb i hrvatske zemlje kao most izmecu srednoeuropskih i mediteranskih glazbenih kultura. Radovis međunarodnog muzikološkog skupa održanog u Zagrebu, Hrvatska, 28. 09.-1. 10. 1994. Urednik Stanislav Tuksar. Zagreb, Hrvatsko muzikološko društvo, 1998. (Muzikološki zbornici, 5). Str. 13-18.

K opredelitvi kompozicijskega idioma zgodnje evropske glasbe. - V: Srednjeveška glasba na Slovenskem in njene evropske vzporednice. Zbornik referatov z mednarodnega simpozija 19. in 20. junija 1997 v Ljubljani. Uredil Jurij Snoj. Ljubljana, Znanstvenoraziskovalni center SAZU, Založba ZRC, 1998. Str. 67-74.

Muzikologija med znanostjo in umetnostjo. Muzikološki zbornik 34/1998, 7-14.

Zgodovina kot začasni vodnik v osmišljanju glasbene izkušnje. Bilten SMD 1998, posebna št., 19-22.

Lebensraum als Schicksal. Anmerkungen zur musikalischen Identität Sloweniens. - V: Kunst-Gespräche. Musikalische Begegnungen zwischen Ost und West. Herausgegeben von Peter Andraschke, Edelgard Spaude. 1. Aufl. Freiburg im Breisgau, Rombach, 1998. (Rombach Wiessenschaft: Reihe Philosophie, 1). Str. 69-78.

Kozmopolitizam s folklornim likom. Bilješke uz Dodolice Borisa Papandopula. Cantus 1998, 99, 8-11. Popisano po podatkih v slovenski vzajemni bibliografski bazi podatkOv COBIB.SI.

\section{Prispevki $v$ enciklopedijah in leksikonih}

Srbija. Srbsko-slovenski odnosi. Kulturni odnosi. Glasba. - V: Enciklopedija Slovenije. 12, Slovenska n-Sz. [Urednica zvezka Alenka Dermastia]. Ljubljana, Mladinska knjiga, 1998. Str. 240-241. Podpis: M. Bmo; sopodpisana: K. Bog. (Katarina Bogunović).

\section{Ocene, poročila}

Glasboslovni vajenci pred ogledalom. Bilten SMD 1998, 11, 55-57. Ocena zbornika: Glasboslovni zapiski. Uredil Gregor Pompe. Ljubljana, Študentski svet Filozofske fakultete, 1998.

Gerhard Funke - Albrecht Riethmüller - Otto Zwierlein: Interpretation. Akademie der Wissenschaft un der Literatur - Mainz, Franz Steiner Verlag, Stuttgart 1998, 53 str. Arti musices 29/1998, 2, 279-283.

\section{9}

\section{Članki}

Humanität und ästhetische Erfarung (zur Zeit einer Musikkultur »außerhalb des Guten und Bösen"). - V: Die Musikentwicklung nach 1968/69. Im Vorzeichen einer Überlebensphilosophie der neuen Musik? Brno, 29.9. -1.10.1997. Komponist und Humanität. Prosa - vertont, tönend gestaltet und musikalisch erlebt. Brno, 28.9. -30.9.1998. Herausgegeben von Petr Macek. Brno, Masarykova univerzita ve spolupráci s Bärenreiter Editio Praha, 1999. Str. 149-152. 
Duša kao poprište zbivanja. Osebujna autorska transpozicija vječne teme u Dvorcu Modrobradog. - V: 20. muzički biennale Zagreb, Međunarodni festival suvremene glazbe, 16. travnja-25. travnja 1999. Urednik Erika Krpan. Zagreb, Hrvatsko društvo skladatelja, Muzički biennale Zagreb, 1999. Str. 32-33.

Musik als Gestalt der begrifflosen Erkenntnis. Filozofski vestnik. Acta philosophica 20/1999, 2, 277-285.

Muzikologija između znanosti i umjetnosti. - V: Glazba, riječi i slike. Svečani zbornik za Koraljku Kos. Uredili Vjera Katalinić, Zdravko Blažeković. Zagreb, Hrvatsko muzikološko društvo, 1999. (Muzikološki zbornici, 6). Str. 345-351.

\section{Prispevki $v$ enciklopedijah in leksikonih}

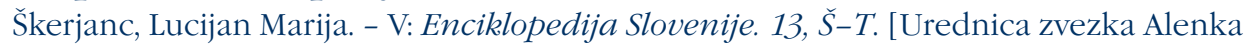
Dermastia]. Ljubljana, Mladinska knjiga, 1999. Str. 41-42. Podpis: M. Bmo.

\section{Ocene, poročila}

Milan Kundera, Iznevjerene oporuke. Esej, prijevod Ana Prpić, Nakladni zavod Matice hrvatske, Zagreb 1997, 200 str., ISBN 953-6014-70-X. Arti musices 30/1999, 1, 133-136.

Brno (Češka) - Međunarodni muzikološki kolokvij, 28.-30. 09. 1998. Arti musices 30/1999, 1, 139-141. Poročilo z znanstvenega skupa.

\section{Mentorstvo}

Luisa Antoni: Ansermetova smer v sodobni fenomenologiji glasbe. Magistrsko delo. Mentor: Tine Hribar; somentorica: Marija Bergamo. Ljubljana, [L. Antoni], 1999. 184 f. Filozofska fakulteta v Ljubljani, Oddelek za filozofijo.

Andrej Rupnik: Funkcija aktivne komunikacije z besedo, gibom, dotikom, glasbo v moji zaznavi, trenutku in okolju. Magistrsko delo. Mentorja: Marija Bergamo, Rastko Močnik. Ljubljana, [A. Rupnik], 1999. 176 f. Institutum Studiorum Humanitatis - Fakulteta za podiplomski humanistični študij.

Leon Stefanija: Umevanje »starega» in "novega"v novejši slovenski glasbi. Doktorska disertacija. Mentorica: Marija Bergamo. Ljubljana, [L. Stefanija], 1999. IV, 266 f., [80] str. Filozofska fakulteta v Ljubljani, Oddelek za muzikologijo.

\section{0}

\section{Članki}

"Lep vrt ob boku zgodovine«. O nekaterih opornih točkah poetike in glasbene dramaturgije Leoša Janáčka. - V: Zbornik ob jubileju Jožeta Sivca. Uredila Jurij Snoj [in] Darja Frelih. Ljubljana, Založba ZRC, ZRC SAZU, 2000. Str. 225-236.

\section{Ocene, poročila}

Usporedni tokovi znanstvenih spoznaja. Glazba, folklor i kultura. Svečani zbornik za Jerka Bezića (ur. N. Ceribašić, V. Katalinić, I. Lozica, G. Marošević, S. Tuksar), izdavači: Institut za etnologiju i folkloristiku i Hrvatsko muzikološko društvo (Serija HMD-a Muzikološki zbornici br. 7), Zagreb 1999. Cantus 2000, 104, 19-20. 


\section{1}

\section{Mentorstvo}

Danijela Lovrić: Josip Mandić: Kapetan Niko. Diplomska naloga. Mentorica: Marija Bergamo. Ljubljana, [D. Lovrić], 2001. 72 f. Filozofska fakulteta v Ljubljani, Oddelek za muzikologijo.

\section{3}

\section{Monografske publikacije}

Glasba kot jezik? Uredila Marija Bergamo. Prevodi: Matjaž Barbo, Marija Bergamo, Aleš Nagode, Leon Stefanija. Ljubljana, Slovensko muzikološko društvo, 2003. (Varia musicologica, 3). Marija Bergamo: Uvodna beseda, str. 5-6. Marija Bergamo je prevedla besedila Inne Barsove, Krzysztofa Guczalskega in Stanislava Tuksarja.

\section{Članki}

Pedeset godina poslije... Gotovčeva opera Ero s onoga svijeta i hrvatska glazbena tradicija. - V: Jakov Gotovac. Uredila Jagoda Martinčević. Zagreb, Muzički informativni centar, Koncertna direkcija, 2003. (Biblioteka Hrvatski glazbenici). Str. 131-146. Vir: Znanstveni skup o Jakovu Gotovcu, Osorske glazbene večeri, avgust 1986.

Glasba kot podoba nepojmovnega spoznavanja. - V: Glasba kot jezik? Uredila Marija Bergamo. Ljubljana, Slovensko muzikološko društvo, 2003. (Varia musicologica, 3). Str. 7-17. Prispevek s tematske konference »Glasba kot jezik«v okviru 14. mednarodnega kongresa za estetiko s temo »Estetika in filozofija $\mathrm{v}$ Ljubljani, 1.-5. septembra 1998.

Glasboslovni instrumentarij v času premen znanstvenih obrazcev. Muzikološki zbornik 39/2003, 1-2, 69-74. Prispevek s simpozija ob 40. letnici Oddelka za muzikologijo na Filozofski fakulteti in ob 10. obletnici delovanja Slovenskega muzikološkega društva. Naslov simpozija: Muzikologija kot nacionalna veda v evropskih in globalnih integracijskih procesih, Ljubljana, 5.11.2002.

\section{Ocene, poročila}

Nasljeđe kao trajna zadaća. Nakon Međunarodnog znanstvenog skupa posvećenog Božidaru Kuncu. Cantus 2003, 124, 32-34.

\section{Spremna besedila}

Skladateljski opus Borisa Papandopula - sloboda u redu. - V: Boris Papandopulo: Kvintet za klarinet i gudački kvartet; Peti gudački kvartet. Sergio Delmastro, klarinet, Zagrebački kvartet. Zagreb, Hrvatsko društvo skladatelja, Cantus, 2003. 1 CD, stereo. (Riznica hrvatske glazbe). Popisano po: Knjižničnem katalogu Nacionalne i sveučilišne knjižnice u Zagrebu (http://katalog.nsk.hr/). 


\section{4}

\section{Članki}

Šulek - Papandopulo: sučeljavanja u sukladnom. - V: Između moderne i avangarde. Hrvatska glazba 1910.-1960. Radovi s muzikološkog skupa održanog u Zagrebu, Hrvatska, 13. - 14.12.1996. Uredila Eva Sedak. Zagreb, Hrvatsko muzikološko društvo, 2004. (Muzikološki zbornici, 11). Str. 91-97.

\section{5}

\section{Monografske publikacije}

Schönberg in njegov krog. Uredila Marija Bergamo in Matjaž Barbo. Prevodi: Matjaž Barbo, Marija Bergamo, Aleš Nagode. Ljubljana, Slovensko muzikološko društvo, 2005. (Varia musicologica, 5). Marija Bergamo: Spremna beseda, str. 107-118. Prevodi del: Vasilij Kandinski, O vprašanju oblike; Nikolaj Kublin, Svobodna glasba; Alban Berg, Zakaj je Schönbergova glasba tako težko razumljiva?; Arnold Schönberg, Nova glasba, zastarela glasba, slog in misel.

\section{Ocene, poročila}

Polikromni portret: Ivo Malec. Autori P. A. Castanet, J. Chr. Thomas, B. Giner, I. Malec, M. Tosi, B. Fort, F. Bayle, hrvatski prevod Marko Gregorić, Titivillus biblioteka, urednik A. Goldstein, Antibarbarus, Zagreb 2005. Cantus 2005, 132, 16-17. Besedilo je prebrano na promociji publikacije v Francoskem institutu, Zagreb, 22.2.2005.

\section{6}

Umetniški značaj proti smotru. Med polariziranjem in harmoniziranjem. De musica disserenda 2/2006, 2, 21-28. - Izvleček v: Glasbeno "uporabno in glasbeno "avtonomno": podobe in pomeni. Mednarodni muzikološki simpozij. Ljubljana, 19. in 20. oktober 2006. Izvlečki. Uredila Nataša Cigoj Krstulović. Ljubljana, Muzikološki inštitut Znanstvenoraziskovalnega centra Slovenske akademije znanosti in umetnosti, 2006. Str. 11. 